\title{
THE IN VITRO AND IN VIVO CAPACITY OF CULTURE-EXPANDED HUMAN CELLS FROM SEVERAL SOURCES ENCAPSULATED IN ALGINATE TO FORM CARTILAGE
}

\author{
M.M. Pleumeekers ${ }^{1}$, L. Nimeskern ${ }^{2}$, W.L.M. Koevoet ${ }^{1}$, N. Kops ${ }^{3}$, R.M.L. Poublon ${ }^{1}$, K.S. Stok ${ }^{2}$ \\ and G.J.V.M. van Osch ${ }^{1,3, *}$
}

\begin{abstract}
${ }^{1}$ Department of Otorhinolaryngology, Head and Neck Surgery, Erasmus MC, University Medical Center, Rotterdam, the Netherlands

${ }^{2}$ Institute for Biomechanics, ETH Zurich, Zurich, Switzerland

${ }^{3}$ Department of Orthopaedics, Erasmus MC, University Medical Center, Rotterdam, the Netherlands
\end{abstract}

\begin{abstract}
Cartilage has limited self-regenerative capacity. Tissue engineering can offer promising solutions for reconstruction of missing or damaged cartilage. A major challenge herein is to define an appropriate cell source that is capable of generating a stable and functional matrix. This study evaluated the performance of culture-expanded human chondrocytes from ear (EC), nose (NC) and articular joint (AC), as well as bone-marrow-derived and adipose-tissuederived mesenchymal stem cells both in vitro and in vivo. All cells ( $\geq 3$ donors per source) were culture-expanded, encapsulated in alginate and cultured for 5 weeks. Subsequently, constructs were implanted subcutaneously for 8 additional weeks. Before and after implantation, glycosaminoglycan (GAG) and collagen content were measured using biochemical assays. Mechanical properties were determined using stress-strain-indentation tests. Hypertrophic differentiation was evaluated with qRT-PCR and subsequent endochondral ossification with histology. ACs had higher chondrogenic potential in vitro than the other cell sources, as assessed by gene expression and GAG content ( $p<0.001)$. However, after implantation, ACs did not further increase their matrix. In contrast, ECs and NCs continued producing matrix in vivo leading to higher GAG content $(p<0.001)$ and elastic modulus. For NC-constructs, matrix-deposition was associated with the elastic modulus $\left(R^{2}=0.477, p=0.039\right)$. Although all cells - except ACs expressed markers for hypertrophic differentiation in vitro, there was no bone formed in vivo. Our work shows that cartilage formation and functionality depends on the cell source used. ACs possess the highest chondrogenic capacity in vitro, while ECs and NCs are most potent in vivo, making them attractive cell sources for cartilage repair.
\end{abstract}

Keywords: Chondrogenesis, chondrocytes, mesenchymal stem cells, alginate, mechanics.

*Address for correspondence:

Prof. dr. Gerjo JVM. van Osch

Erasmus MC, University Medical Center Rotterdam

Dr. Molewaterplein 50-60, Room Ee 16.55

3015 GE Rotterdam

the Netherlands

Telephone Number: +31107043661

FAX Number: +31107044690

E-mail:g.vanosch@erasmusmc.nl

\section{Introduction}

Cartilage is a highly specialised avascular connective tissue located at a variety of anatomical locations such as the ear, nose, trachea, ribs and articular joints. In general, cartilage predominantly consists of an extracellular matrix (ECM), which is produced, maintained and remodelled by a relatively small number of specialised cells (1-10\%) (Muir, 1995). The exact composition of the ECM is mainly dependent on the tissue's function and thus three major subtypes can be distinguished: hyaline, fibrous and elastic cartilage. It is well known that due to its avascular origin, cartilage itself has a limited self-regenerative capacity. As a result, cartilage defects can lead to severe pain, disability and aesthetic impairment. Currently, surgical repair of cartilage requires either autogeneic cartilage grafts or artificial material implants. However, these conventional treatments are (1) associated with a limited availability of autogeneic tissue, (2) can cause donor site morbidity, and - in the case of artificial implants - (3) are prone to generate a foreign body reaction.

To overcome these problems, tissue engineering (TE) can offer a promising solution for restoring missing or damaged cartilage. TE-approaches have focused on the production of functional cartilage that has features similar to native tissue. In cartilage TE, small tissue biopsies are harvested, thus generating minimal donor site morbidity. Cells are isolated from the biopsies and stimulated to proliferate in culture providing large quantities of cells. These cells are subsequently stimulated to produce cartilage tissue which should structurally and morphologically resemble native tissue. One of the major challenges in cartilage TE is defining an appropriate cell source. The most obvious cell source is cartilage itself. Hyaline articular cartilage is most frequently used for cartilage TE, although some experiments have been published on the use of non-articular cartilages (e.g. nasal, ear and costal cartilage) (Stoddart et al., 2009). Next to chondrocytes, mesenchymal stem cells (MSCs) with their multi-lineage differentiation potential and easy availability from bone marrow or adipose tissue have been demonstrated as an attractive cell source for cartilage TE (Johnstone et al., 1998; Pittenger et al., 1999).

To date, we and others have evaluated the use of chondrocytes and MSCs of several anatomical locations for their applicability in cartilage regenerative medicine (Afizah et al., 2007; Asawa et al., 2009; Chung et al., 2008; Hellingman et al., 2011; Henderson et al., 2007; Isogai et al., 2006; Johnson et al., 2004; Kafienah et al., 
2002; Karlsson et al., 2007; Kusuhara et al., 2009; Lohan et al., 2011; Malicev et al., 2009; Naumann et al., 2004; Panossian et al., 2001; Sakaguchi et al., 2005; Seda Tigli et al., 2009; Tay et al., 2004; van Osch et al., 2004; Vinardell et al., 2012; Xu et al., 2004; Yoshimura et al., 2007; Zhang and Spector, 2009). However, precise comparison of the performance of culture-expanded human cells is lacking. This knowledge is important to be able to select an optimal cell source for each application of cartilage TE. The current study was designed to evaluate the performance of culture-expanded cells of several sources for generating a stable and functional ECM in vitro and in vivo. Therefore, human chondrocytes from ear, nose and articular joint and MSCs derived from bone marrow and adipose tissue were compared. Cartilage matrix production was evaluated using qRT-PCR and biochemical assays during in vitro culture. Biochemical assays, histology and mechanical tests were used to determine tissue stability and functionality of cartilage constructs after subsequent subcutaneous implantation in vivo.

\section{Materials and Methods}

\section{Cell sources}

Ear (EC: $n=5$, median age 69, range 17-75 years) and nasal cartilage (NC: $n=8$, median age 24 , range $18-46$ years) were obtained from patients undergoing reconstructive subtotal septorhinoplasty. For articular cartilage (AC), both healthy ( $n=2$, traumatic amputation) and diseased knee cartilage ( $n=7$, osteoarthritis) were harvested. Since no clear differences in chondrogenic potential were visible between both healthy and diseased AC (data not shown), we combined them for further experiments (total $n=9$, median age 68 , range $43-88$ years). To obtain adipose-tissue-derived mesenchymal stem cells (aMSC), subcutaneous abdominal adipose tissue was used from patients undergoing reconstructive breast surgery $(n=7$, median age 51, range 34-71 years). All these tissue samples were obtained as waste material after surgery with approval of the local medical ethics committee (MEC-2011-371). Finally, bone marrow-derived mesenchymal stem cells (bMSC) were harvested from femoral shaft biopsies during total hip replacement surgery, after informed consent had been acquired and with approval of the local medical ethics committee (MEC-2004-142) $(n=11$, median age 63 , range 39-72 years).

\section{Cell isolation and culture \\ Expansion}

To isolate chondrocytes, macroscopically intact cartilage pieces were washed after careful resection of the perichondrium (in the case of nasal and ear cartilage). Cartilage pieces were diced into small fragments and incubated for $1 \mathrm{~h}$ with protease $(2 \mathrm{mg} / \mathrm{mL}$; Sigma-Aldrich, St. Louis, MO, USA), followed by overnight incubation with collagenase B (Roche Diagnostics, Mannheim, Germany) in high glucose (4.5 g/L) Dulbecco's modified Eagle's medium (HG-DMEM; Gibco, Carlsbad, CA, USA) with $10 \%$ foetal calf serum (FCS; Gibco), $50 \mu \mathrm{g}$ / $\mathrm{mL}$ gentamycin (Gibco), and $0.5 \mu \mathrm{g} / \mathrm{mL}$ amphotericin $\mathrm{B}$
(Fungizone; Life Technologies, Breda, the Netherlands). To remove small parts of undigested cartilage, the cell suspension was filtered through a nylon $100 \mu \mathrm{m}$ mesh. Prior to cell seeding, cell viability was tested using the trypan blue exclusion test, and cell number was calculated with a haemocytometer. Chondrocytes were finally seeded at an initial density of 7500 cells/cm 2 in 'standard chondrocyte expansion medium' containing HG-DMEM supplemented with $10 \%$ FCS, $50 \mu \mathrm{g} / \mathrm{mL}$ gentamycin, and $0.5 \mu \mathrm{g} / \mathrm{mL}$ Fungizone.

Bone-marrow-derived heparinised aspirates were seeded at a density of 2-5 x 105 nucleated cells $/ \mathrm{cm} 2$ and cultured overnight in 'standard MSC expansion medium' containing low glucose (1.5 g/L) Dulbecco's modified Eagle's medium (LG-DMEM), supplemented with $10 \%$ FCS; $50 \mu \mathrm{g} / \mathrm{mL}$ gentamycin; $0.5 \mu \mathrm{g} / \mathrm{mL}$ Fungizone; $10-4 \mathrm{M}$ L-ascorbic acid 2-phosphate (Sigma-Aldrich); and $1 \mathrm{ng} / \mathrm{mL}$ basic Fibroblast Growth Factor 2 (bFGF2; AbD Serotec, Kidlington, UK). After $24 \mathrm{~h}$, non-adherent cells and cell debris were washed out and adherent bMSC were further expanded using 'standard MSC expansion medium'.

To extract aMSCs, excised human adipose tissue was washed with LG-DMEM, minced, and suspended in $0.1 \%$ collagenase type I solution (Invitrogen, Carlsbad, CA, USA) in the presence of $1 \%$ bovine serum albumin (BSA; PAA Laboratories Gmbh, Cölbe, Germany) in LG-DMEM. After 60 min of enzymatic digestion on an orbital shaker, floating adipocytes were separated from the precipitating MSC fraction by centrifugation (10 min, 1500 RPM), washed with 'standard MSC expansion medium', and filtered through a $100 \mu \mathrm{m}$ nylon mesh. Before cell seeding, the amount of nucleated cells was assessed using methylene blue, and cell number was calculated with a haemocytometer. The cell suspension was seeded at an initial density of 40,000 cells $/ \mathrm{cm} 2$ in 'standard MSC expansion medium'.

All cells were cultured at $37{ }^{\circ} \mathrm{C}$ in air containing $5 \%$ carbon dioxide. Medium was changed twice a week. When cell cultures reached $80 \%$ confluence, chondrocytes and MSCs were trypsinised using $0.05 \%$ trypsin-EDTA. Chondrocytes were seeded at a 7500 cells/cm 2 and MSCs at a 2300 cells $/ \mathrm{cm} 2$ cell density for further expansion to increase cell number. All third-passage (P3) cells which were approaching subconfluence were detached and cultured in a three-dimensional alginate system (as described below) to promote chondrogenesis.

In order to determine the proliferation rate of cultured ECs, NCs, ACs, bMSCs and aMSCs, growth kinetics of three donors from each cell source were evaluated in monolayer expansion using the number of population doublings (PD) until subconfluency and the time to reach passage four. Therefore, we have calculated the PD/D (Population Doublings per Day) by using the formula: $\mathrm{PD} / \mathrm{D}=(\ln (\mathrm{N} 2 / \mathrm{N} 1) / \ln (2)) / \mathrm{D}$; where N1 was the number of cells at the beginning of each passage, N2 the number of cells at subconfluency, and $\mathrm{D}$ the number of days to reach passage four.

\section{Chondrogenic differentiation}

For three-dimensional alginate culture, isolated cells from four donors of each cartilage source and six donors from 
each of the MSC-sources were suspended at a density of $4 \times 10^{6}$ cells $/ \mathrm{mL}$ in clinical grade $1.1 \%$ low viscosity alginate solution dissolved in $0.9 \% \mathrm{NaCl}$ (Batch MG004, CellMed, Alzenau, Germany). Afterwards, the cell-alginate mixture was transferred into a $10 \mathrm{~mL}$ sterile syringe from which the suspension was slowly passed through a 23-gauge needle to produce drops, which fell into a $102 \mathrm{mM} \mathrm{CaCl}$ solution. Following instantaneous gelation, the beads were allowed to further gelate for a period of 10 min in the $\mathrm{CaCl}_{2}$ solution. After being washed once with $0.9 \% \mathrm{NaCl}$ and $\mathrm{HG}$-DMEM, the beads were transferred to 24-well plates. Controls were cultured in $150 \mu \mathrm{L} /$ bead 'control differentiation medium' containing serum-free HG-DMEM supplemented with $50 \mu \mathrm{g} / \mathrm{mL}$ gentamycin; $0.5 \mu \mathrm{g} / \mathrm{mL}$ Fungizone; $1 \mathrm{mM}$ sodium pyruvate (Gibco); $40 \mu \mathrm{g} / \mathrm{mL}$ L-proline (Sigma-Aldrich); insulin transferrin selenium (ITS+; B\&D Bioscience, Bedford, MA, USA); $10^{-7} \mathrm{M}$ dexamethasone (Sigma-Aldrich); and $25 \mu \mathrm{g} / \mathrm{mL}$ L-ascorbic acid 2-phosphate. In the experimental condition ('chondrogenic differentiation medium'), $10 \mathrm{ng} / \mathrm{mL}$ transforming growth factor $\beta 1$ (TGF $\beta 1$; R\&D Systems, Minneapolis, MN, USA) was added to induce chondrogenesis. Medium was changed twice a week. After two and five weeks, alginate beads were processed for biochemical or gene-expression analysis as described below. For all in vitro experiments, four donors for the chondrocyte sources and six donors for the MSC sources were used, with at least duplicate samples per analyses for each individual donor.

To study in vivo functionality and stability of cartilage TE constructs after in vitro cell culture, larger flat constructs were created from cells of three donors of each cell source as previously described (Wong et al., 2001). In short, alginate suspensions containing $4 \times 10^{6}$ cells $/ \mathrm{mL}$ were injected into a custom-designed slab mould consisting of two calcium-permeable membranes (Durapore ${ }^{\circledR} 5.0 \mu \mathrm{m}$ membrane filters, Millipore, Amsterdam, the Netherlands) rigidly supported by stainless-steel meshes and separated
Table 1. Sequences of primers and probes for qRT-PCR.

\begin{tabular}{|l|l|}
\hline & Primers and probes \\
\hline $\boldsymbol{G A P D H}$ & Forward: ATGGGGAAGGTGAAGGTCG \\
\hline & Reverse: TAAAAGCAGCCCTGGTGACC \\
\hline & Fam-CGCCCAATACGACCAAATCCGTTGAC \\
\hline $\boldsymbol{H P R T 1}$ & Forward: TATGGACAGGACTGAACGTCTTG \\
\hline & Reverse: CACACAGAGGGCTACAATGTG \\
\hline $\boldsymbol{A C A N}$ & Fam-CGCCCAATACGACCAAATCCGTTGAC \\
\hline & Forward: TCGAGGACAGCGAGGCC \\
\hline & Fam-ATGGe: TCGAGGGTGTAGCGTGTAGAGA \\
\hline $\boldsymbol{C O L 2 A 1}$ & Forward: GGCAATAGCAGGTTCACGTACA \\
\hline & Reverse: CGATAACAGTCTTGCCCCACTT \\
\hline & Fam-CCGGTATGTTTCGTGCAGCCATCCT \\
\hline $\boldsymbol{C O L 1 0}$ & Forward: CAAGGCACCATCTCCAGGAA \\
\hline & Reverse: AAAGGGTATTTGTGGCAGCATATT \\
\hline & Fam-TCCAGCACGCAGAATCCATCTGA \\
\hline $\boldsymbol{A L P}$ & Forward: GACCCTTGACCCCCACAAT \\
\hline & Reverse: GCTCGACTGCATGTCCCCT \\
\hline & Fam-TGGACTACCTATTGGGTCTCTTCGAGCCA \\
\hline $\boldsymbol{M M P 1 3}$ & Forward: AAGGAGCATGGCGACTTCT \\
\hline & Reverse: TGGCCCAGGAGGAAAAGC \\
\hline & Fam-CCCTCTGGCCTGCGGCTCA \\
\hline & \\
\hline
\end{tabular}

by a stainless-steel casting frame. Part of these constructs were harvested after five weeks of cell culture for analysis and a part was implanted subcutaneously on the dorsal side of athymic mice. For the in vivo experiments, a total of six constructs per cell source were used, with duplicate samples for three different donors.

\section{Subcutaneous implantation in vivo}

In total, seventeen nine-week old, female NMRI nu/ nu mice (Charles River Laboratories, Wilmington,

Table 2. The Bern Score: Histological evaluation of engineered cartilage constructs.

\begin{tabular}{|l|l|c|}
\hline Scoring categories & Score \\
\hline $\mathbf{( 1 )}$ & Uniformity and darkness of the stain & 0 \\
\hline & No stain & 1 \\
\hline & Weak stain of poorly formed matrix & 2 \\
\hline & Moderately even stain & 3 \\
\hline & Even dark stain & 0 \\
\hline $\mathbf{( 2 )}$ & Distance between cells / amount of matrix accumulated & 1 \\
\hline & High cell densities with no matrix in between (no spacing between cells) & 2 \\
\hline & High cell densities with little matrix in between (cells <1 cell-size apart) & 3 \\
\hline & Moderate cell density with matrix (cells approximately 1 cell-size apart) & \\
\hline & Low cell density with moderate distance between cells (>1 cell) and an extensive matrix & 0 \\
\hline $\mathbf{( 3 )}$ & Cell morphologies represented & 1 \\
\hline & Condensed/necrotic/pycnotic bodies & 2 \\
\hline & Spindle/fibrous & 3 \\
\hline & Mixed spindle/fibrous with rounded chondrogenic morphology & $\mathbf{9}$ \\
\hline & Majority rounded/chondrogenic & \\
\hline & MAXIMUM SCORE &
\end{tabular}


MA, USA) were used to evaluate the performance of constructs cultured with or without TGF $\beta 1$. Mice were placed under general anaesthesia using $2.5 \%$ isoflurane. Two separate subcutaneous incisions of approximately $10 \mathrm{~mm}$ were made along the central line of the spine (one at the shoulders and one at the hips), after which four separate subcutaneous pockets were prepared by blunt dissection of the subcutaneous tissue. For implantation, the alginate constructs were randomly assigned to these four pockets. Eight weeks after subcutaneous implantation, animals were sacrificed and samples were explanted for histological, biomechanical and biochemical analyses. Animal experiments were carried out with approval of the local Animal Experiments Committee of the Erasmus $\mathrm{MC}$ and were approved as outlined in the national Animals Act (EMC 2429).

\section{Gene expression analyses}

For total RNA isolation, alginate was dissolved in icecold $55 \mathrm{mM}$ sodium citrate $(150 \mu \mathrm{L} /$ bead $)$ and $20 \mathrm{mM}$ ethylenediaminetetraacetate (EDTA) in $150 \mathrm{mM} \mathrm{NaCl}$ and centrifuged at $2.5 \mathrm{~g}$ for $8 \mathrm{~min}$. Each pellet was subsequently suspended in $1 \mathrm{~mL}$ RNA-Bee ${ }^{\mathrm{TM}}$ (Tel-Test, Friendswood, TX, USA). RNA was extracted with chloroform and purified from the supernatant using the RNAeasy Micro Kit (Qiagen, Hilden, Germany) according to the manufacturer's guidelines by on-column DNA-digestion. Extracted total RNA was quantified using NanoDrop ${ }^{\circledR}$ ND-1000 Spectrophotometer (NanoDrop Technologies, Wilmington, DE, USA) at 260/280 nm. Total RNA of each sample was reverse transcribed into cDNA using RevertAid $^{\mathrm{TM}}$ First Strand cDNA Synthesis Kit (MBI Fermentas, St. Leon-Rot, Germany).

For quantitative real-time polymerase chain reaction (qRT-PCR) analysis, forward and reverse primers were designed using PrimerExpress 2.0 software (Applied Biosystems, Foster City, CA, USA) to meet TaqMan or SYBR Green requirements. They were designed to bind separate exons to avoid co-amplification of genomic DNA. Gene specificity of all primers was guaranteed by basic local alignment search tool (BLASTN), as listed in Table 1. The following genes were analysed: aggrecan $(A C A N)$, collagen type IIA1 (COL2A1), collagen type X (COL10), alkaline phosphatase $(A L P)$, and matrix metalloproteinase-13 (MMP13). Glyceraldehyde 3-phosphate dehydrogenase $(G A P D H)$, and hypoxanthine phosphoribosyltransferase 1 (HPRT1) were used as housekeeping genes. The expression of GAPDH and HPRT1 did not differ between cell sources and both were used to calculate the best housekeeper index (Pfaffl et al., 2004). Using repeated pair-wise correlation analysis, data were normalised by calculating the 'best housekeeper index' (data not shown). Polymerase chain reactions were performed using TaqMan ${ }^{\circledR}$ Universal PCR Mastermix (Applied Biosystems) or qPCR Mastermix Plus for SYBR Green (Eurogentec, Nederland BV, Maastricht, the Netherlands) according to the manufacturers' guidelines and using an ABIPRISM ${ }^{\circledR} 7000$ with SDS software version 1.7 (Applied Biosystems, Nieuwerkerk a/d IJssel, the Netherlands). Amplification efficiencies for all assays were between $90-110 \%$. Relative gene expressions of triplicate samples of each donor were calculated by means of the $2^{-\Delta \mathrm{CT}}$ formula.

\section{Biochemical evaluation of the extracellular matrix Sample preparation}

At room temperature, alginate beads and discs were dissolved in $55 \mathrm{mM}$ sodium citrate and $20 \mathrm{mM}$ EDTA in $150 \mathrm{mM} \mathrm{NaCl}$. All samples were then digested overnight at $60{ }^{\circ} \mathrm{C}$ with papain buffer to a final concentration of $250 \mu \mathrm{g} /$ $\mathrm{mL}$ papain $\left(0.2 \mathrm{M} \mathrm{NaH}_{2} \mathrm{PO}_{4}, 0.01 \mathrm{M}\right.$ EDTA, pH 6.0, and freshly added $250 \mu \mathrm{g} / \mathrm{mL}$ papain and $5 \mathrm{mM}$ L-cysteine), and later subjected to biochemical analyses to determine the DNA, glycosaminoglycan, and hydroxyproline contents.

\section{DNA content}

The amount of DNA measured in each papain-digested sample was determined by ethidium bromide (Gibco), using calf thymus DNA (Sigma-Aldrich) as a standard. Samples were analysed with a spectrofluorometer (Wallac 1420 Victor 2; Perkin-Elmer, Wellesley, MA, USA), using an extinction filter (340 $\mathrm{nm}$ ) and an emission filter $(590 \mathrm{~nm})$.

\section{Glycosaminoglycan content}

Sulphated glycosaminoglycans (GAGs) were quantified using the 1,9-dimethylmethylene blue (DMMB) dyebinding assay. To be suitable for cell cultures containing alginate, the DMMB-pH-level was decreased to $\mathrm{pH} 1.75$, as described previously (Enobakhare et al., 1996). The metachromatic reaction of DMMB was monitored using a spectrophotometer. Absorption ratios of 540 and $595 \mathrm{~nm}$ were used to determine the GAG content with chondroitin sulphate C (shark; Sigma-Aldrich) as a standard. For each sample, the amount of GAG was corrected for the amount of DNA.

\section{Hydroxyproline content}

The hydroxyproline content was quantified using a method described previously (Creemers et al., 1997). Briefly, the papain digests were hydrolysed with equal volumes of $12 \mathrm{M}$ $\mathrm{HCl}$ at $108^{\circ} \mathrm{C}$ for $18-20 \mathrm{~h}$. Samples were then dried and redissolved in $150 \mu \mathrm{L}$ water. Hydroxyproline contents were measured using a colorimetric method (extinction, $570 \mathrm{~nm}$ ), with chloramine-T and dimethylaminobenzaldehyde as reagents and hydroxyproline (Merck, Darmstadt, Germany) as a standard.

\section{Histological evaluation of the extracellular matrix}

After eight weeks of subcutaneous implantation, alginate discs were harvested, set in $2 \%$ agarose, fixed in $4 \%$ formalin in PBS and embedded in paraffin. Paraffinembedded sections $(6 \mu \mathrm{m})$ were deparaffinised and rehydrated.

\section{Immunohistochemistry for collagen type II, elastin and human vimentin}

To allow the use of monoclonal mouse antibodies on constructs which have been implanted in athymic mice, we used a method to couple the first and second antibody before applying them on the sections to prevent 
unwanted binding of the anti-mouse antibodies to mouseimmunoglobulins (Hierck et al., 1994). In short, primary antibodies were pre-coupled overnight with goat antimouse biotin at $4{ }^{\circ} \mathrm{C}$ (Jackson Laboratories, Bar Harbor, ME, USA), followed by a $2 \mathrm{~h}$ incubation in $0.1 \%$ normal mouse serum (CLB, Amsterdam, the Netherlands) in order to capture the unbound second antibody.

Antigen retrieval for the collagen type II antibody (Developmental Studies Hybridoma Bank, Iowa City, IA, USA) was performed through incubation with $0.1 \%$ pronase (Sigma-Aldrich) in PBS for $30 \mathrm{~min}$ at $37^{\circ} \mathrm{C}$, continued with a $30 \mathrm{~min}$ incubation with $1 \%$ hyaluronidase (Sigma-Aldrich) in PBS at $37{ }^{\circ} \mathrm{C}$. Antigen retrieval for elastin (BA4, Sigma-Aldrich) required incubation with $0.25 \%$ trypsin (Sigma-Aldrich) in PBS for $20 \mathrm{~min}$ at $37^{\circ} \mathrm{C}$. Non-specific binding sites were blocked with $10 \%$ goat serum (Sigma-Aldrich) in PBS and sections were stained with the pre-treated primary antibodies against collagen type II (1:100) or elastin $(1: 1000)$ for $60 \mathrm{~min}$. Sections were than incubated with enzyme-streptavidin conjugate (Label, 1:100, Biogenex, HK-321-UK, San Ramon, CA, USA) in PBS, $1 \%$ BSA, followed by incubation with Neu Fuchsin substrate (Chroma, Köngen, Germany). Positive staining for collagen II and elastin was confirmed with the use of native ear cartilage. A mouse monoclonal negative control antibody (mIgG1: X0931, Dako, Eindhoven, the Netherlands) was used as an isotype control.

To study whether cells in the alginate constructs harvested after in vivo implantation were of human origin, a monoclonal mouse anti-human vimentin antibody was used (AMF-17b, Developmental Studies Hybridoma Bank), as described previously (Hellingman et al., 2011). In short, slides were incubated in $3 \%$ aqueous hydrogen peroxidase solution, in order to inhibit endogenous peroxidase and allow for peroxidase-antiperoxidase staining. Antigen retrieval required incubation in Rodent Decloaker ${ }^{\circledR}$ for $60 \mathrm{~min}$ at $95^{\circ} \mathrm{C}$. Non-specific binding sites were blocked with Rodent Block $\mathrm{M}^{\circledR}$ followed by a $30 \mathrm{~min}$ staining with vimentin (1:40, V6630, Sigma-Aldrich). Thereafter, the MM-polymer-HRP ${ }^{\circledR}$ secondary antibody was used, followed by incubation with 3'diaminobenzidine chromogen solution (Sigma-Aldrich). Tissue specificity was confirmed by the absence of staining on sections of mouse liver tissue. A mouse monoclonal negative control antibody was used as an isotype control.

\section{Von Kossa/Thionin/Resorcin-Fuchsin staining}

To evaluate tissue calcification, a Von Kossa staining was performed. Slides were immersed in $5 \%$ silver nitrate solution (Sigma-Aldrich) for $10 \mathrm{~min}$, rinsed in MiliQ water and exposed to light for another $10 \mathrm{~min}$. Sections were counterstained with Nuclear fast red (Merck, Rayway, NJ, USA).

GAGs were visualised using $0.4 \%$ Thionin (SigmaAldrich) in $0.01 \mathrm{M}$ aqueous sodium acetate ( $\mathrm{pH} 4.5)$ for $5 \mathrm{~min}$ at room temperature. To check whether we stained GAGs rather than the remaining alginate, sections were pre-treated with $20 \mathrm{mM}$ EDTA (Sigma-Aldrich). As EDTA treatment did not change the intensity and/or localisation of thionin on our slides, we confirmed that alginate did not interfere with our GAG-staining protocol. The presence, as well as the arrangement of the elastic fibres, was visualised using Weigert's Resorcin-Fuchsin staining (Klinipath, Duiven, the Netherlands).

We used a semi-quantitative scoring system - The Bern Score (Grogan et al., 2006) - to evaluate the chondrogenic capacity of alginate-encapsulated cells after subcutaneous implantation (Table 2). In short, the scoring system evaluates cartilage formation based on three elements: (1) the uniformity and/or intensity of the thionin and collagen type II staining; (2) the distance between cells and the extent of matrix produced; and (3) the cellular morphology. Each category has scores ranging from 0 to 3 , resulting in a possible minimum collective score of 0 and a maximum of 9. Samples that were either not visible anymore after eight weeks of subcutaneous implantation or were dissolved during formalin fixation were scored 0 .

\section{Biomechanical analysis}

For mechanical characterisation of engineered cartilage constructs after in vitro and in vivo cell culture, we used $2.5 \mathrm{~mm}$ thick and $5 \mathrm{~mm}$ diameter constructs. The samples were placed in a close-fitting $\varnothing 5 \mathrm{~mm}$ stainless steel cylindrical wells. Mechanical testing was performed with a materials testing machine (Zwick Z005, Ulm, Germany) equipped with a $10 \mathrm{~N}$ load cell, a built-in displacement control, and a cylindrical, plane-ended, stainless steel indenter $(\varnothing 1.2 \mathrm{~mm})$. During mechanical testing the samples were immersed in PBS. Stress-strain testing was performed: the samples were compressed to a final height of $0.5 \mathrm{~mm}$ at a loading rate of $5 \mathrm{~mm}$ per min. An in-house Matlab ${ }^{\circledR}$ script was used to locate the sample surface and measure the sample thickness. The sample surface was identified by detecting the corresponding slope discontinuity of the force-displacement curve using its second derivative. Force-displacement curves were then converted to stress-strain curves. Compressive modulus at $40 \%$ strain $(\mathrm{E} 40 \%)$, defined as the derivative of the stress-strain curve at $40 \%$ strain, was determined for every sample $(n=98)$.

\section{Statistical analysis}

All data were analysed with PASW Statistics 20.0 (SPSS inc. Chicago, IL, USA). The mean and standard deviations are presented. For statistical evaluation, a mixed linear model was used. Cell source, time point and treatment (TGF $\beta 1$ ) were defined as fixed factors in the model. Donor and sample number were treated as random factors. Values of $p<0.05$ were considered statistically significant. For histological scoring we used the Kruskal-Wallis followed by the Mann-Whitney $U$ tests for their statistical analysis $(p<0.05)$. In order to determine whether mechanical properties were enhanced by the deposition of matrix components, a multiple regression analyses was performed using GAG and collagen deposition as independent variables $(p<0.05)$. 


\section{Results}

\section{Cell expansion}

The cell sources showed clear differences in growth rate. NCs proliferated significantly faster than ECs, ACs and aMSCs $(p<0.05)$. NCs had gone through $8.9 \pm 1.7$ population doublings (PD) in four passages taking $28 \pm 5 \mathrm{~d}$, ECs had gone through $6.8 \pm 1.3 \mathrm{PD}$ in $38 \pm 6 \mathrm{~d}$ and ACs through $3.9 \pm 1.1 \mathrm{PD}$ in $44 \pm 13 \mathrm{~d}$. It took $39 \pm 8 \mathrm{~d}$ for bMSCs and $48 \pm 8 \mathrm{~d}$ for aMSCs to complete 4 passages (Table 3).

\section{Chondrogenic differentiation in vitro}

After cell-expansion, cells were encapsulated in clinicalgrade alginate to promote chondrogenesis. Alginate beads cultured without TGF $\beta 1$ had maintained their DNA content after 5 weeks of culture. Addition of TGF $\beta 1$ significantly increased the total amount of DNA in alginate beads seeded with ECs and NCs $(p<0.001)$, which was also significantly higher compared to the other cell sources $(p<0.05)$, indicating that those cells were able to proliferate after encapsulation in alginate. The other cell conditions remained at a stable cell content (Fig. 1A).

Chondrocytes did express low levels of COL2A1 and $A C A N$ without TGF $\beta 1$. After chondrogenic induction (with TGF $\beta 1$ ), the COL2A1 and $A C A N$ gene expression levels increased in all cell sources used. Both genes were most highly expressed by ACs $(p<0.001)$, followed by bMSCs (Fig. 1B). This was already seen after 2 weeks of culture (data not shown), suggesting that chondrogenesis was not only enhanced but also accelerated.

Matrix production was quantified by GAG and collagen content of alginate beads during in vitro culture. Without TGF $\beta 1$ very little GAG was formed in vitro. Addition of TGF $\beta 1$ enhanced GAG production and after 5 weeks of culture ACs deposited significantly more GAGs $(p<0.01)$. When GAG content was adjusted to the amount of DNA, similar but more pronounced differences were observed (ACs produced most GAGs: $60.89 \pm 53.04 \mu \mathrm{g}$ GAG / $\mu \mathrm{g}$ DNA; $p<0.001)$. GAG content per alginate bead in constructs containing bMSCs, ECs, NCs and aMSCs was not significantly different, although a large donor variation was observed. Also with large variation between donors, aMSCs performed worse. The amount of collagen deposited was just above background for all cell sources after 5 weeks of chondrogenic differentiation, being on average $1.53 \pm 1.84 \mu \mathrm{g}$ collagen per alginate bead (Fig. 1C).

\section{Chondrogenic differentiation in vivo}

To study the stability and quality of TE cartilage in vivo, alginate constructs were first differentiated in vitro for 5 weeks and subsequently implanted subcutaneously on the dorsal side of athymic mice for an additional 8 weeks of culture. Constructs seeded with ECs or NCs, pre-cultured with TGF $\beta 1$, had a macroscopically white opaque appearance and were relatively strong on handling. Conversely, constructs pre-cultured without TGF $\beta 1$ or constructs encapsulating ACs, bMSCs or aMSCs, were fragile and also did not resemble cartilaginous tissue macroscopically (Figs. 2A and 3A).

Prior to implantation, constructs pre-cultured without TGF $\beta 1$ produced very little GAG in vitro, being on average $1.10 \pm 1.20 \mu \mathrm{g}$ GAG per construct. After in vivo implantation, these constructs greatly increased their production of matrix components, although they did not reach levels which equalled the matrix content found in constructs cultured with TGF $\beta 1$ (Fig. 2B). After subcutaneous implantation preceded by chondrogenic culture (with TGF $\beta 1$ ), ACs, bMSCs and aMSCs retained their GAG content but did not further increase it. In contrast, ECs and NCs significantly enhanced matrix formation in vivo (EC 7.26-fold and NC 2.86-fold; both $p<0.001$ ) leading to a superior GAG deposition after implantation compared to the other cell sources (both $p<0.001$ ). These results were further confirmed by Thionin-staining (data not shown). Total collagen deposition was hugely increased after implantation and no significant differences could be detected between the different cell sources (Fig. 3B).

Constructs containing ACs, bMSCs or aMSCs exhibited a very weak staining for cartilage-specific collagen type II (Fig. 3C), which was in contrast to the overall production of collagens (Fig. 3B), thus indicating that other collagens were also produced (e.g. collagen type I or type III). The cartilage matrix of constructs containing ECs and NCs showed a strong staining for collagen type II, although

Table 3. Population doubling time of different cell types over four passages.

\begin{tabular}{|c|c|c|}
\hline & PD/D & Statistically significantly different from \\
\hline EC & $\mathbf{0 . 1 8} \pm \mathbf{0 . 0 4}$ & $\mathrm{NC}(p=0.015) ; \mathrm{AC}(p=0.008)$ \\
\hline NC & $\mathbf{0 . 3 2} \pm \mathbf{0 . 0 7}$ & $\mathrm{EC}(p=0.015) ; \mathrm{AC}(p<0.001) ; \operatorname{aMSC}(p=0.013)$ \\
\hline AC & $\mathbf{0 . 1 0} \pm \mathbf{0 . 0 5}$ & $\mathrm{EC}(p=0.008) ; \mathrm{NC}(p<0.001) ; \operatorname{bMSC}(p=0.001)$ \\
\hline bMSC & $\mathbf{0 . 2 5} \pm \mathbf{0 . 0 9}$ & $\mathrm{AC}(p=0.001)$ \\
\hline aMSC & $\mathbf{0 . 1 6} \pm \mathbf{0 . 0 4}$ & $\mathrm{NC}(p=0.013)$ \\
\hline
\end{tabular}

NCs proliferated faster than ECs, ACs and aMSCs. The proliferation rate of bMSCs did not differ from aMSCs. Data are shown as mean \pm SD. PD/D = population doublings per day $(\mathrm{PD} / \mathrm{D}=(\ln (\mathrm{N} 2 / \mathrm{N} 1) / \ln (2)) / \mathrm{D}) ; \mathrm{EC}=$ ear chondrocytes ( $n=3$ donors); $\mathrm{NC}=$ nasal chondrocytes $(n=3$ donors); $\mathrm{AC}=$ articular chondrocytes $(n=3$ donors); bMSC $=$ bone marrow-derived mesenchymal stem cells ( $n=3$ donors); aMSC $=$ adipose tissue-derived mesenchymal stem cells ( $n=3$ donors). 
A

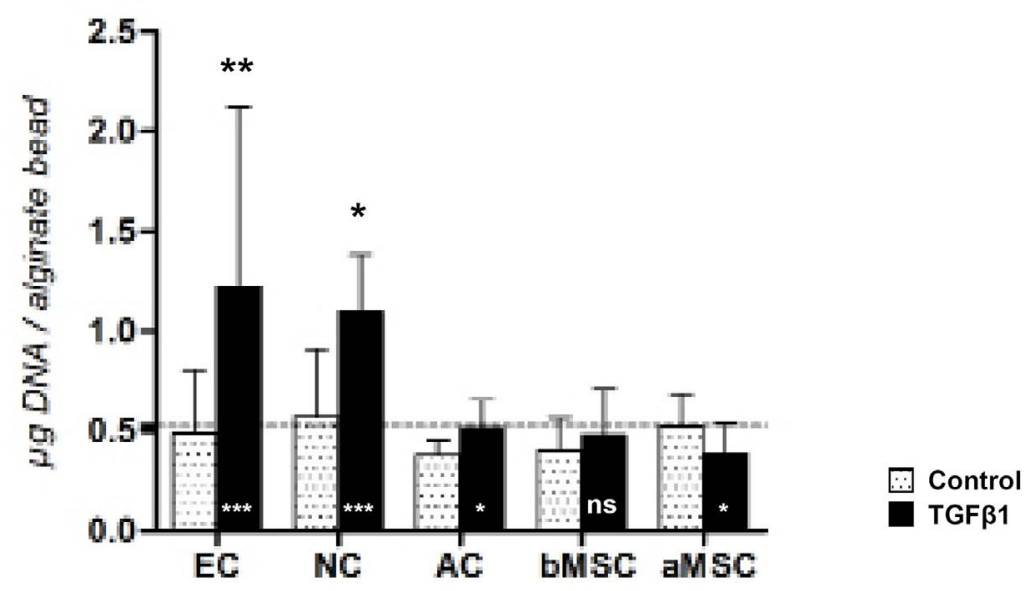

B
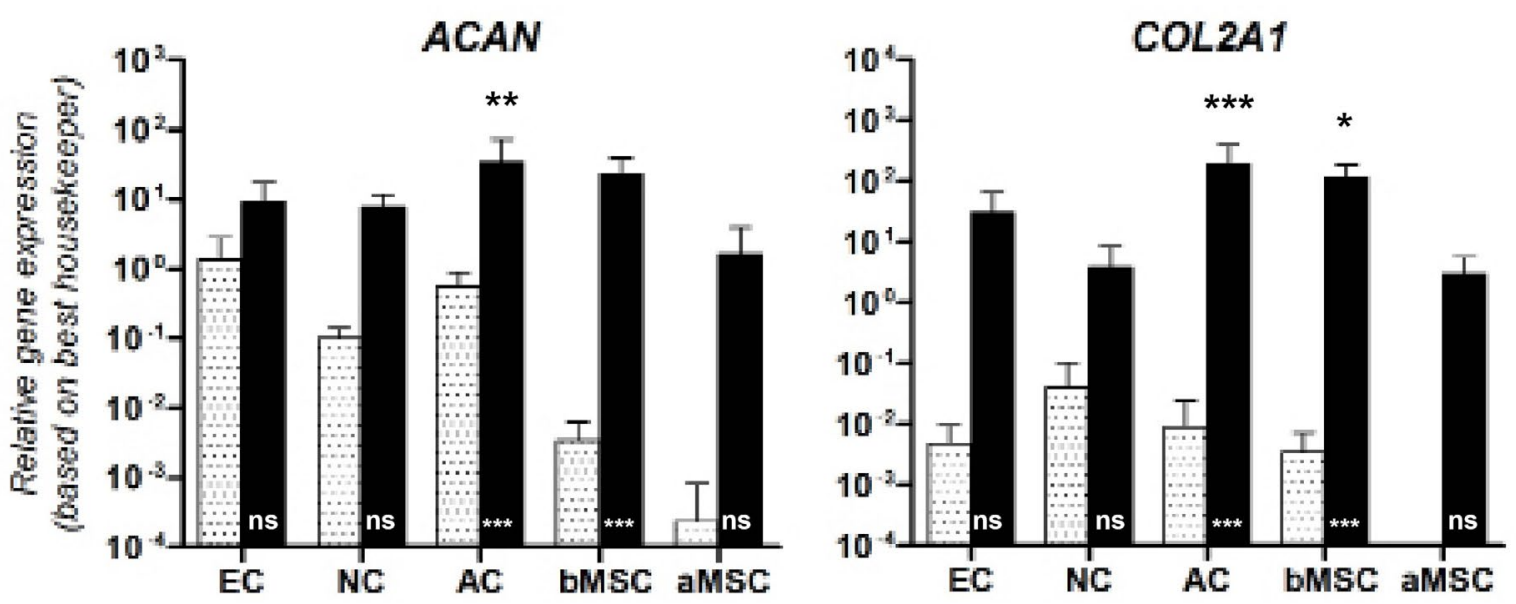

C
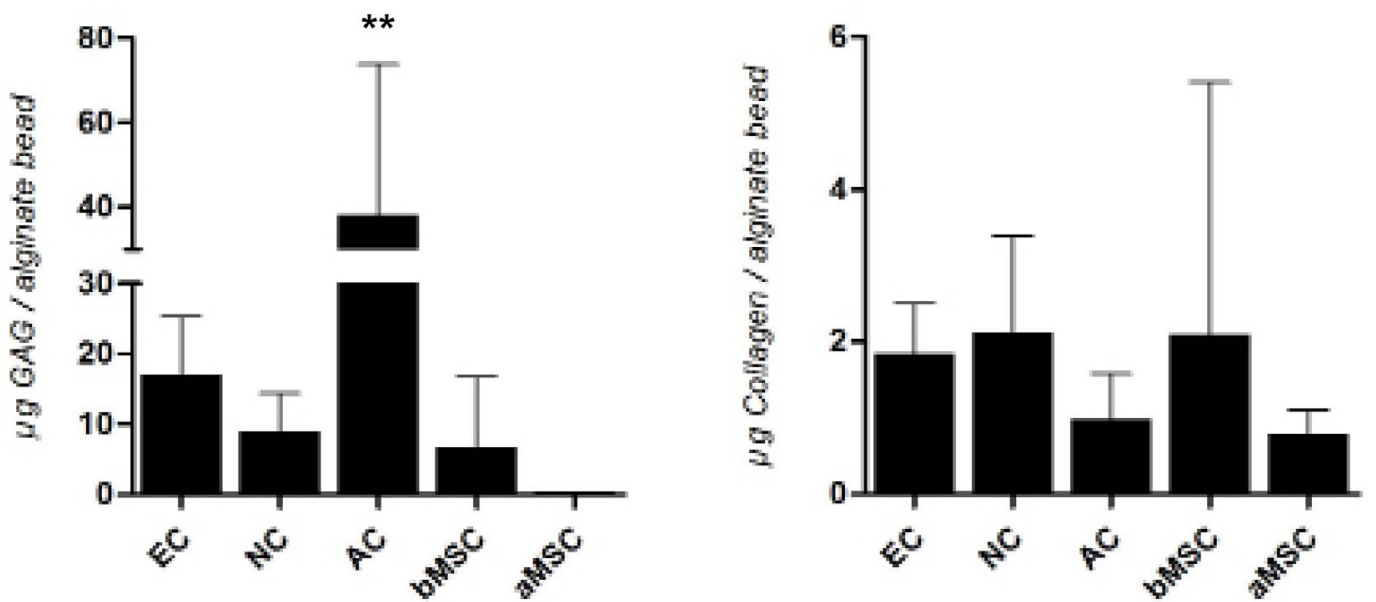

Fig. 1. Cartilage matrix formation by several cell types in vitro. To promote chondrogenesis, cells were encapsulated in alginate beads and cultured without (dotted) or with (black) TGF $\beta 1$ for 5 weeks. (A) Cell content. DNA content was determined before culture (dotted line), being on average $0.53 \pm 0.183 \mu \mathrm{g}$ DNA per alginate bead, and after 5 weeks of culture. The amount of DNA was significantly higher in constructs containing ECs or NCs. (B) Gene-expression analyses. Relative gene expression levels of $C O L 2 A 1$ and $A C A N$ were corrected for the best housekeeper index. All cell sources expressed $A C A N$ and $C O L 2 A 1$ after chondrogenic induction. (C) Biochemical analyses. Biochemical evaluation of the glycosaminoglycan (GAG) and collagen content after chondrogenic induction in alginate beads. ACs deposited most GAGs. Collagen production was low in vitro. Data are shown as mean $\pm \mathrm{SD}$. For statistical evaluation, a mixed model was used. $*, * *$ or $* * *$ indicates $p$-values less than $0.05,0.01$ or 0.001 , respectively, compared to the control condition (asterisk is shown in the bar) or compared to the other cell sources (asterisk is shown above the bar). EC $=$ ear chondrocytes $(n=4$ donors $) ; \mathrm{NC}=$ nasal chondrocytes $(n=4$ donors $) ; \mathrm{AC}=\operatorname{articular}$ chondrocytes $(n=4$ donors); bMSC $=$ bone marrow-derived mesenchymal stem cells $(n=6$ donors $)$ aMSC $=$ adipose tissue-derived mesenchymal stem cells ( $n=6$ donors). Per donor, 2-3 samples were used for analyses. 
A

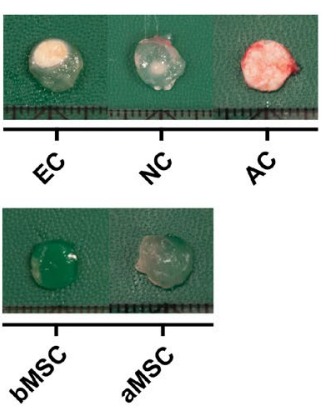

B
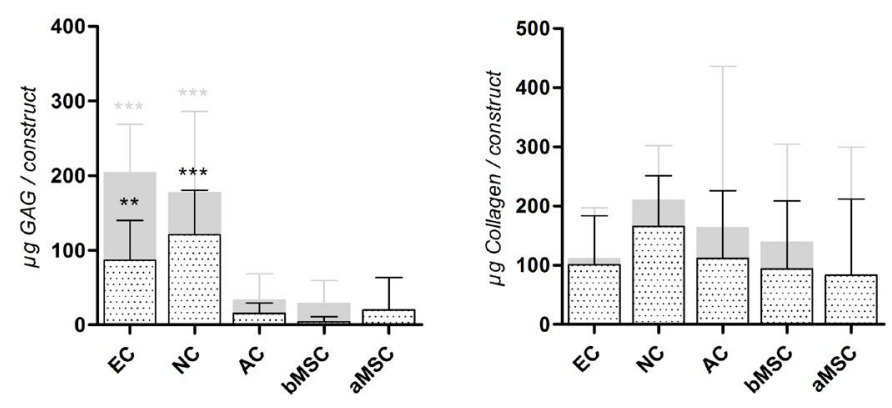

C

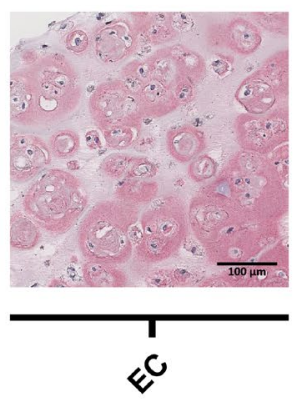

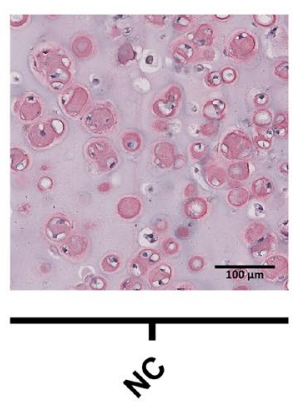

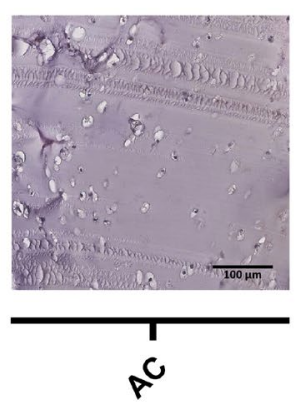

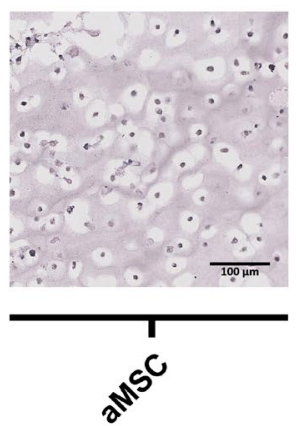

Fig. 2. Cartilage matrix formation by several cell types in vivo. Prior to subcutaneous implantation, constructs were cultured in vitro for 5 weeks in the absence of TGF $\beta 1$. (A) Macroscopic view of engineered cartilage constructs after 8 weeks of subcutaneous implantation. (B) Biochemical analyses. Biochemical evaluation of the glycosaminoglycan (GAG) and collagen content after subcutaneous implantation on the dorsal side of athymic mice. ECs and NCs deposited most GAGs in vivo. Collagen production was increased in vivo, but did not differ between the cell sources. The grey bars represent the in vivo biochemical data of constructs cultured in vitro for 5 weeks in the presence of TGF $\beta 1$ (Fig. 3). (C) Immunohistochemical analyses of collagen type II. ECs and NCs demonstrated a collagen type II-rich matrix in almost all cartilage constructs. Biochemical data are shown as mean $\pm \mathrm{SD}$. For statistical evaluation, a mixed model was used. *, ** or $* * *$ indicates $p$-value less than $0.05,0.01$ or 0.001 , respectively, compared to the other cell sources. $\mathrm{EC}=$ ear chondrocytes $(n=3$ donors); $\mathrm{NC}=$ nasal chondrocytes $(n=3$ donors); $\mathrm{AC}=$ articular chondrocytes $(n=3$ donors); $\mathrm{bMSC}=$ bone marrow-derived mesenchymal stem cells $(n=3$ donors $)$; aMSC $=$ adipose tissue-derived mesenchymal stem cells ( $n=3$ donors). Per donor, 2 samples were used for analyses.

dissimilar distributions of collagen type-II fibres within the cartilage matrices were apparent. The semi-quantitative histological scores of constructs containing ECs or NCs were significantly better than the scores of the other cell sources (Fig. 3C).

The presence of elastin was determined to evaluate differentiation into elastic cartilage. There was no elastin detectable in any of the constructs with an elastin immunostaining after 5 weeks of in vitro cell culture (data not shown). After subcutaneous implantation, elastin was only present in alginate constructs containing ECs, and predominantly found in constructs which were pre-cultured with TGF $\beta 1$. Most elastin was located around the cell (Fig. 3D).

To ensure that these cartilage constructs were of human origin, a human-specific vimentin stain was used on histological sections. It confirmed that the cartilage constructs were indeed of human origin (Fig. 3E), while the surrounding fibrous tissue was not (data not shown).

\section{Cartilage stability}

Hypertrophic differentiation is an unwanted phenomenon in cartilage regeneration, resulting in cartilage that can remodel into bone when implanted in vivo. To evaluate hypertrophy in vitro, we have studied gene expression of a panel of three hypertrophic markers during 5 weeks of cell culture (i.e. COL10, ALP and MMP13; Fig. 4A). Cultured with TGF $\beta 1, C O L 10$ expression was highest in NCs $(p<0.05)$ and bMSCs $(p<0.001)$, and was minimally expressed by ACs. MMP13 was expressed by all cells and significantly highest in NCs. $A L P$ was significantly higher in constructs with bMSCs compared to the other cell sources $(p<0.05)$. In addition, constructs with bMSCs already expressed high $C O L 10$ and $A L P$ after 2 weeks of culture, indicating early hypertrophic differentiation (data not shown).

Although bMSCs expressed all hypertrophic markers in vitro, they did not mineralise or form bone after 8 weeks of subcutaneous implantation. Also, no signs of tissue calcification or bone formation were observed in constructs containing aMSCs. In contrast, $100 \%$ (3/3) of the cell-free constructs and, unexpectedly, $58.3 \%$ (7/12) of constructs encapsulating ACs did calcify in vivo. Also, calcification was more often seen in constructs pre-cultured in control medium (without TGF $\beta 1$ ) compared to constructs cultured in chondrogenic medium (with TGF $\beta 1$ ) (Fig. 4B). 
A

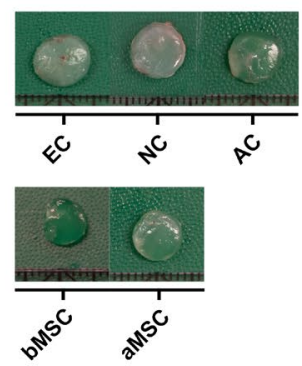

C

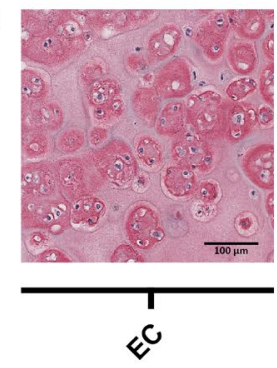

B

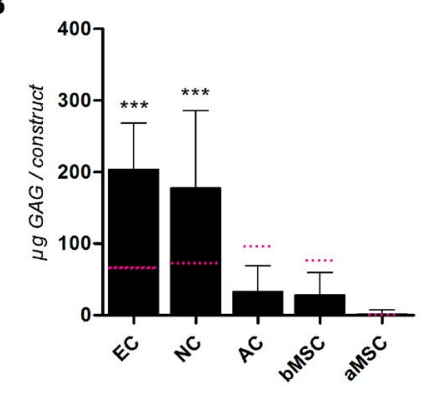

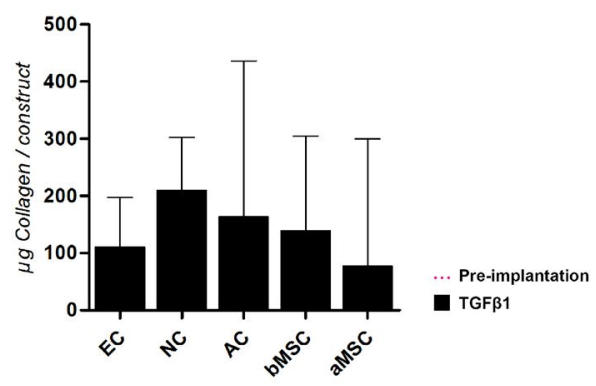
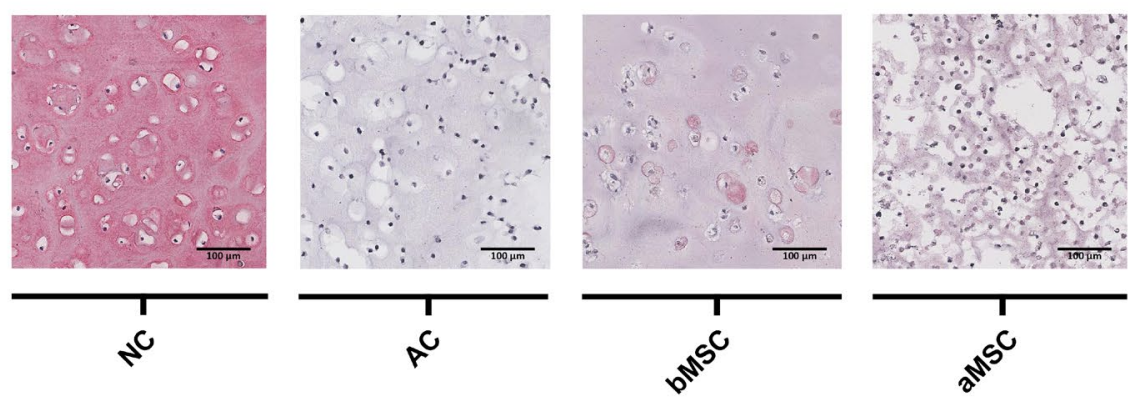

D
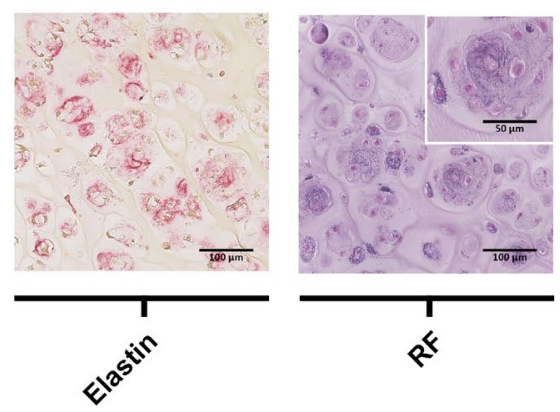

E
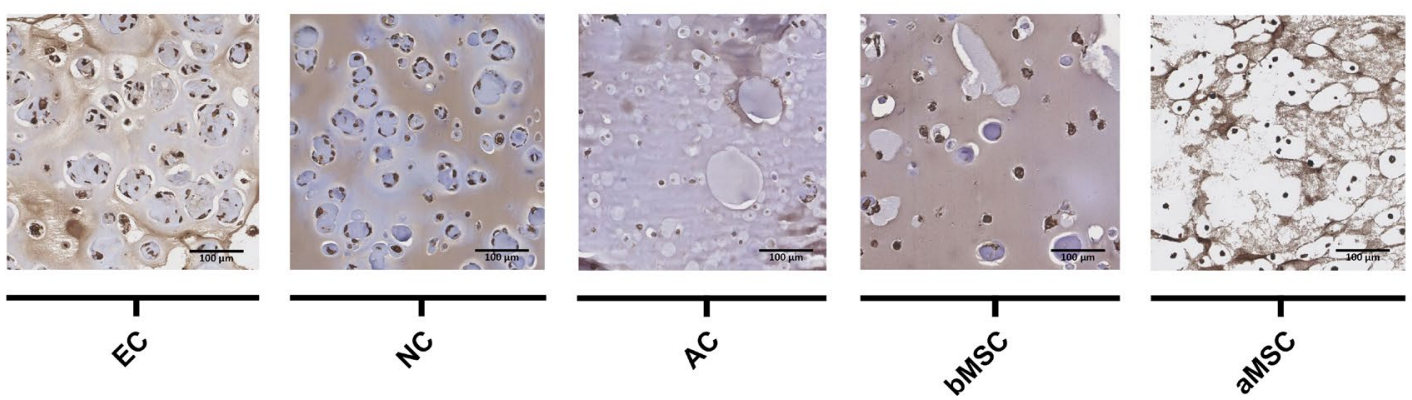

Fig. 3. Cartilage matrix formation by several cell types in vivo. Prior to subcutaneous implantation, constructs were cultured in vitro for 5 weeks in the presence of TGF $\beta 1$. (A) Macroscopic view of engineered cartilage constructs after 8 weeks of subcutaneous implantation. (B) Biochemical analyses. Biochemical evaluation of the glycosaminoglycan (GAG) and collagen content after subcutaneous implantation on the dorsal side of athymic mice. ECs and NCs deposited most GAGs in vivo. Collagen production was increased in vivo, but did not differ between the cell sources. (C) Collagen type II. ECs and NCs demonstrated a collagen type II-rich matrix in almost all cartilage constructs, leading to significantly better semi-quantitative Bern's scores than the other cell sources. (D) Elastin. Elastin was not formed in vitro. After subcutaneous implantation, only constructs containing ECs were able to produce elastin. Most elastin fibres were found around the cell. Elastin = Immunohistochemical staining for elastin; RF = Resorchin Fuchsin, chemical staining for elastin. (E) Human vimentin. All cartilage constructs were of human origin. Biochemical data are shown as mean \pm SD. For statistical evaluation, a mixed model was used. Histological data are shown as the median of individual data points. For statistical evaluation, a Kruskal-Wallis test was used followed by Mann-Whitney-U comparison. *, ** or *** indicates $p$-values less than $0.05,0.01$ or 0.001 , respectively, compared to the other cell sources. EC $=$ ear chondrocytes ( $n=3$ donors); $\mathrm{NC}=$ nasal chondrocytes $(n=3$ donors); $\mathrm{AC}=\operatorname{articular}$ chondrocytes $(n=3$ donors $)$; bMSC $=$ bone marrow-derived mesenchymal stem cells ( $n=3$ donors); aMSC $=$ adipose tissue-derived mesenchymal stem cells $(n=3$ donors). Per donor, 2 samples were used for analyses. 
A
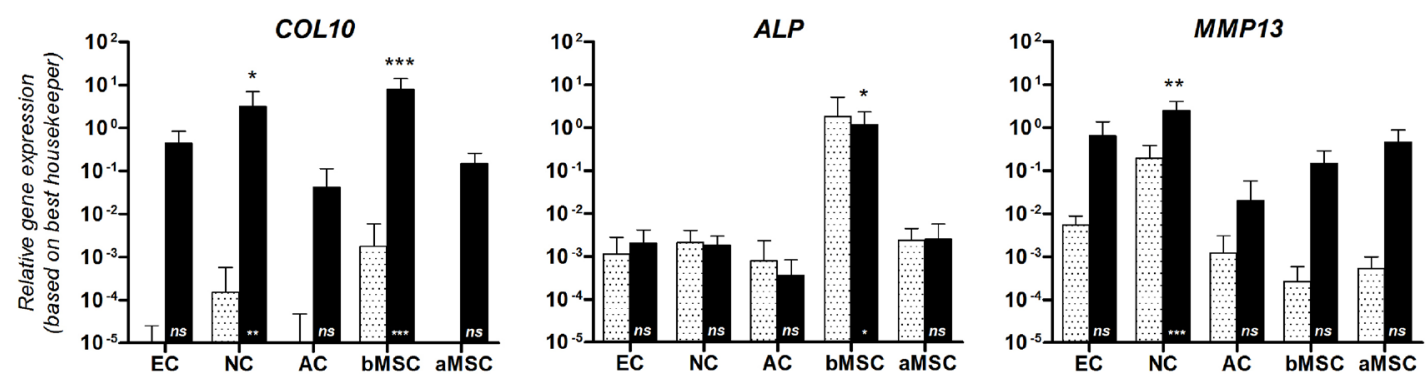

B

\begin{tabular}{|c|c|c|}
\hline & Control & TGF $\boldsymbol{\beta} 1$ \\
\hline EC & $1 / 6$ & $0 / 6$ \\
\hline NC & $1 / 6$ & $0 / 6$ \\
\hline AC & $4 / 6$ & $3 / 6$ \\
\hline bMSC & $0 / 6$ & $0 / 6$ \\
\hline aMSC & $0 / 6$ & $0 / 6$ \\
\hline Alginate & $3 / 3$ & - \\
\hline
\end{tabular}
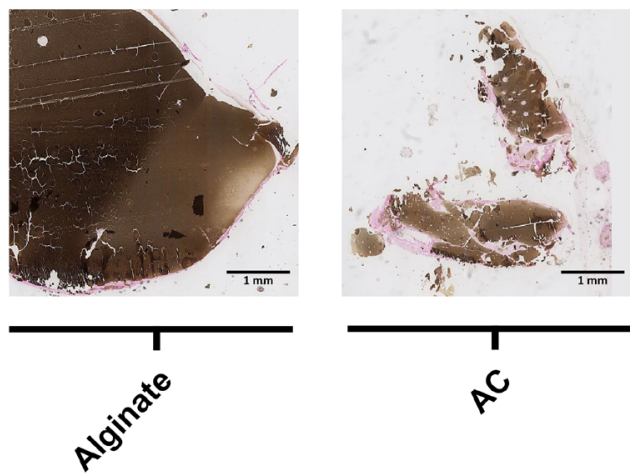

Fig. 4. Stability of cartilage constructs in vitro and in vivo. (A) Hypertrophy in vitro. Relative gene expression levels of COL10, ALP and MMP13 were examined after 5 weeks of culture and corrected for the best housekeeper index. Hypertrophic genes were most highly expressed by bMSCs and NCs. Data are shown as mean \pm SD. For statistical evaluation, a mixed model was used. $* * *$ or $* * *$ indicates $p$-values less than $0.05,0.01$ or 0.001 , respectively, compared to the control condition (asterisk is shown in the bar) or compared to the other cell sources (asterisk is shown above the bar). EC, NC and AC: $n=4$ donors each; bMSC, aMSC: $n=6$ donors each. (B) Mineralisation in vivo. Von Kossa staining was used to evaluate construct calcification in vivo. MSCs did not calcify the construct in vivo. Non-seeded alginate and constructs encapsulating ACs did calcify. For each cell source we had a total of 6 alginate constructs: duplicate samples of 3 different donors. $\mathrm{EC}=$ ear chondrocytes; $\mathrm{NC}=$ nasal chondrocytes; $\mathrm{AC}=$ articular chondrocytes; bMSC = bone marrow-derived mesenchymal stem cells; aMSC = adipose tissue-derived mesenchymal stem cells.
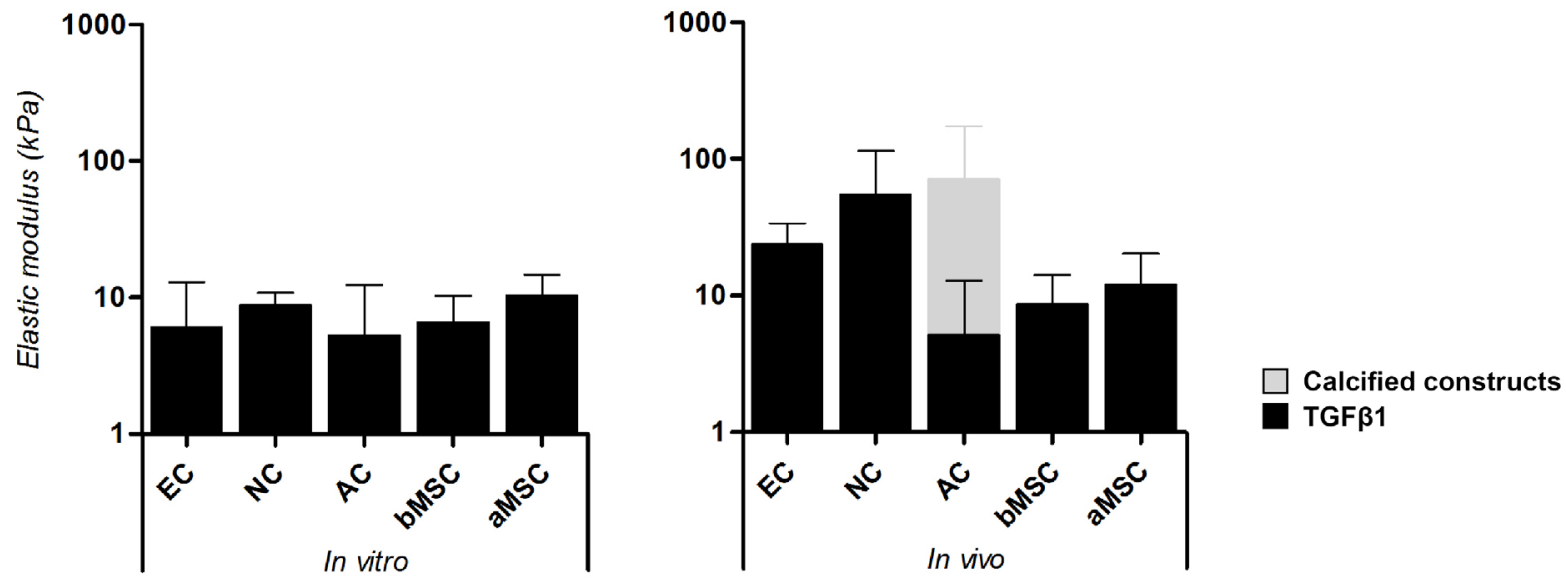

Fig. 5. Biomechanical evaluation of constructs with different cell types. Biomechanical properties enhanced after in vivo implantation. ECs and NCs tended to exhibit superior mechanical properties in vivo compared to the other cell sources. Since tissue calcification misrepresents the biomechanical properties of the cartilage matrix; we excluded calcified cartilage constructs for further analyses (grey bar represents the mechanical properties of both calcified and non-calcified constructs). Biomechanical data are shown as mean $\pm \mathrm{SD}$. EC $=$ ear chondrocytes $(n=3$ donors); $\mathrm{NC}=$ nasal chondrocytes $(n=3$ donors $) ; \mathrm{AC}=\operatorname{articular}$ chondrocytes $(n=3$ donors $) ; \mathrm{bMSC}=$ bone marrow-derived mesenchymal stem cells ( $n=3$ donors); aMSC $=$ adipose tissue-derived mesenchymal stem cells $(n=3$ donors). Per donor, 2 samples were used for analyses. 


\section{Cartilage structure and functionality}

The elastic modulus of constructs was low in vitro, irrespective of the cell source used, being on average $7.42 \pm 2.10 \mathrm{kPa}$. However, after subcutaneous implantation, mechanical properties improved in constructs containing either ECs $(23.68 \pm 10.20)$ or NCs $(55.12 \pm 59.25)$, but was not perceived in constructs containing ACs, bMSCs or aMSCs (Fig. 5). Since tissue calcification misrepresents the biomechanical properties of the cartilage matrix; we excluded calcified cartilage constructs from further analyses.

To determine whether the mechanical properties were enhanced by the deposition of matrix components, a multiple regression analyses was performed for all cell sources separately using GAG and collagen deposition as independent variables. Only for constructs containing $\mathrm{NCs}$, matrix components significantly associated with the biomechanical functionality of the constructs $\left(R^{2}=0.477\right.$, $F=4.558, p=0.039$ ). For these constructs, only GAG deposition associated significantly with the biomechanical properties of the cartilage constructs independently (GAG: $\beta=0.689, p=0.013$; collagen: $\beta=0.044, p=0.851$ ).

\section{Discussion}

For successful regeneration of cartilage tissue, selection of the most appropriate cell source is crucial. This study demonstrates that cartilage matrix formation and functionality is cell source dependent; articular chondrocytes (ACs) possess the highest chondrogenic capacity in vitro, while ear chondrocytes (ECs) and nasal chondrocytes (NCs) are most potent for cartilage regeneration after subcutaneous implantation in vivo.

To date, we and others have evaluated the use of chondrocytes and mesenchymal stem cells (MSCs) from several anatomical locations for their applicability in cartilage regenerative medicine (Afizah et al., 2007; Asawa et al., 2009; Chung et al., 2008; Hellingman et al., 2011; Henderson et al., 2007; Isogai et al., 2006; Johnson et al., 2004; Kafienah et al., 2002; Karlsson et al., 2007; Kusuhara et al., 2009; Lohan et al., 2011; Malicev et al., 2009; Naumann et al., 2004; Panossian et al., 2001; Sakaguchi et al., 2005; Seda Tigli et al., 2009; Tay et al., 2004; van Osch et al., 2004; Vinardell et al., 2012; Xu et al., 2004; Yoshimura et al., 2007; Zhang and Spector, 2009). However, these studies often used non-expanded cells isolated from animals. Moreover, a detailed direct comparison between various chondrocyte and MSCsources was lacking. Therefore, this study is the first to systematically compare the quality and tissue stability of engineered cartilage constructs produced by cultureexpanded ACs, NCs, ECs, bMSCs and aMSCs of human origin.

We have used culture-expanded human cells, to closely simulate the clinical situation. For clinical application, the use of autogeneic cells is favourable, since these cells do not elicit a tissue rejection response. However, it has been difficult to obtain appropriate numbers of cells, as donor tissue is limited and harvesting can cause large donor site morbidity. Consequently, monolayer cell expansion has become an essential step in the process of cartilage TE. To fulfil this requirement, we culture-expanded all cells for four passages. It was obvious that different cells went through a different number of population doublings during these four passages; ACs had gone through the least number of population doublings confirming earlier findings of slow proliferation of ACs (Henderson et al., 2007; Isogai et al., 2006; Kafienah et al., 2002; van Osch et al., 2004).

To be able to use expanded cells for the reconstruction of cartilage defects, cells should be stimulated to regain their cartilage-matrix-forming capacity. Several research groups have shown that expanded cells can regain their chondrogenic potential under specific culture conditions: (1) the use of a 3D-culture system, and/or (2) the administration of chondrogenic factors, such as TGF $\beta$ (Yaeger et al., 1997). In order to generate a 3D-culture environment, we have encapsulated all cells in clinical grade alginate, since alginate enables a homogeneous cell distribution, prevents cells from floating out while permitting nutrient diffusion and oxygen transfer to the encapsulated cells, and promotes the synthesis of cartilagespecific matrix components, such as GAGs and collagen type II (Hauselmann et al., 1992). Surprisingly, we showed that alginate appears to have the tendency to calcify in vivo, since $20 \%$ of all constructs calcified during subcutaneous implantation. Especially, cell-free constructs and constructs encapsulating ACs suffered from this phenomenon. Also, calcification was more often seen in constructs precultured in medium without TGF $\beta 1$. To our knowledge, calcium-cross-linked alginate calcifies through binding the surrounding phosphate ions to form calcium phosphate crystals. These crystals are stable in neutral to basic environments and do not appear at $\mathrm{pH}$ of less than 6.8 (Lee et al., 2010). We believe that the calcified constructs were possibly generated in a neutral to alkaline environment prior to implantation, since these constructs were either not metabolically active (non-seeded alginate) or had a low metabolic activity due to stable cartilage formation (ACs) or due to the deficiency of TGF $\beta 1$. Obviously, in these constructs, calcification did not seem to be a consequence of instable cartilage formation, but was more likely a typical characteristic of alginate itself. Surprisingly and in contrast to our previous work with MSCs in collagen scaffolds (Farrell et al., 2009) or in pellets without scaffold (Hellingman et al., 2012), constructs containing MSCs (both bMSCs and aMSCs) never mineralised in vivo, although signs of endochondral differentiation were observed prior to implantation. The absence of endochondral ossification during in vivo implantation was accompanied by lack of neovascularisation or vessel ingrowth within the matrix, which is known to be extremely important for endochondral ossification (Kanczler and Oreffo, 2008). We believe that alginate prevented this process, by the fact that endothelial cells lack receptors to bind to alginate polymers, prohibiting neovascularisation or vessel ingrowth (Alsberg et al., 2001). Therefore, it seemed that alginate could be an excellent cell-carrying 
gel for cartilage regeneration, although future work needs to clarify which approach is required to exclude alginate calcification after in vivo implantation.

In addition to a 3D-culture environment, specific growth and differentiation factors will help to regain and induce a chondrocyte-like phenotype. In vitro, cultureexpanded cells of all sources studied failed to differentiate towards the chondrogenic lineage in the absence of TGF $\beta 1$, as assessed by an almost negligible deposition of GAGs and the inferior expression of both $A C A N$ and COL2A1 in alginate constructs. The presence of TGF $\beta 1$ induced chondrogenic differentiation in vitro, where ACs exhibit a superior chondrogenic capacity in vitro, compared to the other cell sources. The beneficial effect of culturing with TGF $\beta 1$ during in vivo chondrogenesis was present, although less obvious. Constructs cultured without TGF $\beta 1$ increased their production of matrix components after in vivo implantation, but were not able to reach levels found in constructs cultured with TGF $\beta 1$.

Even after four passages of culture expansion, chondrocytes demonstrated some clear subtype specific differences. Firstly, ACs possessed the highest chondrogenic capacity in vitro, but were not able to further increase their cartilage matrix in vivo. The inability of ACs to promote cartilage formation in vivo may be due to the lack of mechanical loading or growth factor stimulation after subcutaneous implantation, which may have led to a loss of chondrogenic capacity. ACs, different from the other cell sources, are exposed to mechanical loading within native articular cartilage and unloading is known to induce GAG-release from the cartilage matrix and to reduce cell proliferation and GAG synthesis within the matrix (Tomiya et al., 2009). Secondly, chondrocytes from ear cartilage were able to form an elastin network after subcutaneous implantation in vivo. Elastin was predominantly found in constructs which were cultured with TGF $\beta 1$. In vitro culture did not demonstrate elastin deposition at all, which was in accordance with our previous work (Hellingman et al., 2011). The capability of culture-expanded ECs to produce elastin in vivo suggests that these cells retain their capability to form an elastic cartilage matrix. Both findings - the inability of ACs to promote cartilage formation in vivo without mechanical loading and the ability of cultured expanded ECs to produce elastin - indicate that both cell types preserved their subtype specific phenotype after culture expansion, confirming our previous study where gene expression profiles of culture-expanded NCs and ECs displayed clear differences that were related to their developmental origin (Hellingman et al., 2011).

Besides chondrocytes, MSCs have been demonstrated to be an attractive cell source for cartilage TE (Barry et al., 2001; Caplan, 1991; Johnstone et al., 1998; Pittenger et al., 1999). Although bone marrow offers the most common source of MSCs, adipose tissue has been proven to be an attractive alternative in respect to the abundant and easily accessible pool of MSCs (Zuk et al., 2002; Zuk et al., 2001). We have demonstrated that both bMSCs and aMSCs underwent chondrogenic differentiation in vitro and in vivo, although matrix production was less than in constructs containing chondrocytes (ACs, NCs or ECs).
Constructs containing bMSCs had a higher chondrogenic potential than aMSCs, demonstrated by an increased $A C A N$ and COL2A1 gene-expression and an improved GAG deposition. With the exception of a few studies (De Ugarte et al., 2003; Izadpanah et al., 2006; Kern et al., 2006; Lee et al., 2004), this confirms other studies (Afizah et al., 2007; Huang et al., 2005; Im et al., 2005; Liu et al., 2007; Mehlhorn et al., 2006; Noel et al., 2008; Rebelatto et al., 2008; Rider et al., 2008; Sakaguchi et al., 2005; Segawa et al., 2009; Winter et al., 2003). Nevertheless, the assumptions that MSCs are fundamentally less chondrogenic than chondrocytes, and that bMSCs are more in favour for cartilage regeneration than aMSCs, seems unjustified. It appears that cell culture conditions for both bMSCs and aMSCs remain to be improved. For instance, it was found that another member of the TGF $\beta$ superfamily, bone morphogenetic protein 6 , is obligatory to improve chondrogenic differentiation in aMSCs (Estes et al., 2010).

Finally, in order to understand how the distribution and composition of matrix components resulted in a mechanically functional cartilage matrix, the compositional-biomechanical relationship of the cartilage constructs was evaluated. After in vivo implantation, mechanical properties increased in constructs containing ECs and NCs. Only for constructs containing NCs, matrix components were significantly correlated to their biomechanical functionality. It is already known that GAGs and collagens, the main components of the ECM, are both associated with the biomechanical properties of native cartilage: (1) the negatively charged GAGs provide an osmotic pressure within the tissue; and (2) the architecture of the collagen network captures the GAGs and prevents them from leaking out of the tissue (Han et al., 2011). In contrast, the elastic fibre network in constructs containing ECs might have influenced the biomechanical properties in vivo as well, although the exact contribution of elastin to mechanical functionality is not yet fully understood. Besides the existence of matrix components, the quality of the matrix is not only determined by the amount of matrix components deposited, but also influenced by the number of cross-links between matrix molecules (i.e. collagen cross-links) (Bastiaansen-Jenniskens et al., 2008a). The distribution of matrix components in the ECM was clearly different between cell sources: ECs deposited most matrix components pericellularly, whereas NCs deposited these matrix components homogenously throughout their matrix, which was clearly visible on the immunohistochemical collagen type II staining. It is well known that a heterogeneously distributed matrix alters the biomechanical properties of the matrix, as the physical properties are determined by the weakest point in the matrix (Mow and Guo, 2002).

The present study has certain limitations. Firstly, cell density plays a critical role in functional and stable cartilage formation. Others have demonstrated that cell densities greater than $20 \times 10^{6}$ cells per $\mathrm{mL}$ are desirable, while low cell densities resulted in decreased cartilage formation (Puelacher et al., 1994). Therefore, a potential drawback of our study is that we only could use a cell-seeding 
density of $4 \times 10^{6}$ cells per $\mathrm{mL}$ of alginate, since the size of our experimental set-up did not enable higher densities. Secondly, as mentioned before, we have culture-expanded all cells until passage four to obtain a sufficient number of cells. In order to be able to compare all different cell sources, we have used standardised protocols for the culture expansion of both chondrocytes and MSCs. Differences in expansion rates between the different cells were obvious. While culture expansion is associated with chondrocyte dedifferentiation and replicative cell senescence, the enforcement of population doublings instead of culture passages might have been more appropriate, since population doublings more accurately reflect cell growth and thus cell aging. However, since nasal chondrocytes had most doublings in four passages but still produced most cartilage, a direct link between doublings and cartilage formation seems unlikely. How all the parameters such as number of doublings, expansion speed, initial seeding density, growth factors present in the medium or produced by the cells themselves exactly determine dedifferentiation and possible loss of chondrogenic capacity during monolayer expansion remains to be elucidated. Finally, we have demonstrated large donor variation in constructs containing ACs or bMSCs. Nevertheless these differences were not based on a donor-age effect nor explained by the use of healthy versus diseased ACs. Moreover, donors for nasal cartilage appeared younger than other sources. Although there is a possibility that the donor age has influenced the general outcome of our study, improved chondrogenic and proliferative capacity of nasal chondrocytes was also stated by others in the literature (Kafienah et al., 2002; Naumann et al., 2004; Tay et al., 2004).

In summary, we have demonstrated that cartilage matrix formation and functionality are cell source dependent. Articular chondrocytes possess the highest chondrogenic capacity in vitro, while ear and nasal chondrocytes are most potent for cartilage regeneration after subcutaneous implantation, making ear and nasal chondrocytes attractive cell sources for future cell-based cartilage repair. Only for constructs containing nasal chondrocytes, GAG and collagen content were associated with biomechanical functionality of the constructs, indicating the differences in matrix component assembly by different cell sources. The inability of articular chondrocytes to increase cartilage matrix in vivo may be due to a loss of chondrogenic capacity in the absence of mechanical loading or growth factor stimulation. Although mesenchymal stem cells are considered as a promising cell source for the reconstruction of cartilage defects, it appears that improvements in cell culture conditions for both bone-marrow-derived and adipose tissue-derived mesenchymal stem cells are needed.

\section{Acknowledgments}

The authors thank the Departments of Orthopaedic Surgery, Plastic and Reconstructive Surgery, and Otorhinolaryngology at Erasmus MC for their assistance in obtaining ear, nasal and articular cartilage as well as bone marrow and adipose tissue, and CellMed (Alzenau,
Germany) for providing the clinical grade alginate. The study was performed within the framework of EuroNanoMed (EAREG-406340-131009/1) and funded by SenterNovem (ENM09001). We wish to confirm that there are no known conflicts of interest associated with this publication and there has been no significant financial support for this work that could have influenced its outcome.

\section{References}

Afizah H, Yang Z, Hui JH, Ouyang HW, Lee EH (2007) A comparison between the chondrogenic potential of human bone marrow stem cells (BMSCs) and adiposederived stem cells (ADSCs) taken from the same donors. Tissue Eng 13: 659-666.

Alsberg E, Anderson KW, Albeiruti A, Franceschi RT, Mooney DJ (2001) Cell-interactive alginate hydrogels for bone tissue engineering. J Dent Res 80: 2025-2029.

Asawa Y, Ogasawara T, Takahashi T, Yamaoka H, Nishizawa S, Matsudaira K, Mori Y, Takato T, Hoshi K (2009) Aptitude of auricular and nasoseptal chondrocytes cultured under a monolayer or three-dimensional condition for cartilage tissue engineering. Tissue Eng Part A 15: 1109-1118.

Barry F, Boynton RE, Liu B, Murphy JM (2001) Chondrogenic differentiation of mesenchymal stem cells from bone marrow: differentiation-dependent gene expression of matrix components. Exp Cell Res 268: 189200.

Bastiaansen-Jenniskens YM, Koevoet W, De Bart AC, Zuurmond AM, Bank RA, Verhaar JA, DeGroot J, van Osch GJ (2008a) TGFbeta affects collagen cross-linking independent of chondrocyte phenotype but strongly depending on physical environment. Tissue Eng Part A 14: 1059-1066.

Caplan AI (1991) Mesenchymal stem cells. J Orthop Res 9: 641-650.

Chung C, Erickson IE, Mauck RL, Burdick JA (2008) Differential behavior of auricular and articular chondrocytes in hyaluronic acid hydrogels. Tissue Eng Part A 14: 1121-1131.

Creemers LB, Jansen DC, van Veen-Reurings A, van den Bos T, Everts V (1997) Microassay for the assessment of low levels of hydroxyproline. BioTechniques 22: 656658.

De Ugarte DA, Morizono K, Elbarbary A, Alfonso Z, Zuk PA, Zhu M, Dragoo JL, Ashjian P, Thomas B, Benhaim P, Chen I, Fraser J, Hedrick MH (2003) Comparison of multi-lineage cells from human adipose tissue and bone marrow. Cells Tissues Organs 174: 101-109.

Enobakhare BO, Bader DL, LeeDA(1996)Quantification of sulfated glycosaminoglycans in chondrocyte/alginate cultures, by use of 1,9-dimethylmethylene blue. Anal Biochem 243: 189-191.

Estes BT, Diekman BO, Gimble JM, Guilak F (2010) Isolation of adipose-derived stem cells and their induction to a chondrogenic phenotype. Nat Protoc 5: 1294-1311.

Farrell E, van der Jagt OP, Koevoet W, Kops N, van Manen CJ, Hellingman CA, Jahr H, O’Brien FJ, Verhaar 
JA, Weinans H, van Osch GJ (2009) Chondrogenic priming of human bone marrow stromal cells: a better route to bone repair? Tissue Eng Part C Methods 15: 285-295.

Grogan SP, Barbero A, Winkelmann V, Rieser F, Fitzsimmons JS, O’Driscoll S, Martin I, Mainil-Varlet P (2006) Visual histological grading system for the evaluation of in vitro-generated neocartilage. Tissue Eng 12: 2141-2149.

Han EH, Chen SS, Klisch SM, Sah RL (2011) Contribution of proteoglycan osmotic swelling pressure to the compressive properties of articular cartilage. Biophys J 101: 916-924.

Hauselmann HJ, Aydelotte MB, Schumacher BL, Kuettner KE, Gitelis SH, Thonar EJ (1992) Synthesis and turnover of proteoglycans by human and bovine adult articular chondrocytes cultured in alginate beads. Matrix 12: 116-129.

Hellingman CA, Verwiel ET, Slagt I, Koevoet W, Poublon RM, Nolst-Trenite GJ, Baatenburg de Jong RJ, Jahr H, van Osch GJ (2011) Differences in cartilageforming capacity of expanded human chondrocytes from ear and nose and their gene expression profiles. Cell Transplant 20: 925-940.

Hellingman CA, Koevoet W, van Osch GJ (2012) Can one generate stable hyaline cartilage from adult mesenchymal stem cells? A developmental approach. J Tissue Eng Regen Med 6: e1-e11.

Henderson JH, Welter JF, Mansour JM, Niyibizi C, Caplan AI, Dennis JE (2007) Cartilage tissue engineering for laryngotracheal reconstruction: comparison of chondrocytes from three anatomic locations in the rabbit. Tissue Eng 13: 843-853.

Hierck BP, Iperen LV, Gittenberger-De Groot AC, Poelmann RE (1994) Modified indirect immunodetection allows study of murine tissue with mouse monoclonal antibodies. J Histochem Cytochem 42: 1499-1502.

Huang JI, Kazmi N, Durbhakula MM, Hering TM, Yoo JU, Johnstone B (2005) Chondrogenic potential of progenitor cells derived from human bone marrow and adipose tissue: a patient-matched comparison. J Orthop Res 23: 1383-1389.

Im GI, Shin YW, Lee KB (2005) Do adipose tissuederived mesenchymal stem cells have the same osteogenic and chondrogenic potential as bone marrow-derived cells? Osteoarthritis Cartilage 13: 845-853.

Isogai N, Kusuhara H, Ikada Y, Ohtani H, Jacquet R, Hillyer J, Lowder E, Landis WJ (2006) Comparison of different chondrocytes for use in tissue engineering of cartilage model structures. Tissue Eng 12: 691-703.

Izadpanah R, Trygg C, Patel B, Kriedt C, Dufour J, Gimble JM, Bunnell BA (2006) Biologic properties of mesenchymal stem cells derived from bone marrow and adipose tissue. J Cell Biochem 99: 1285-1297.

Johnson TS, Xu JW, Zaporojan VV, Mesa JM, Weinand C, Randolph MA, Bonassar LJ, Winograd JM, Yaremchuk MJ (2004) Integrative repair of cartilage with articular and nonarticular chondrocytes. Tissue Eng 10: 1308-1315.

Johnstone B, Hering TM, Caplan AI, Goldberg VM, Yoo JU (1998) In vitro chondrogenesis of bone marrowderived mesenchymal progenitor cells. Exp Cell Res 238: 265-272.
Kafienah W, Jakob M, Demarteau O, Frazer A, Barker MD, Martin I, Hollander AP (2002) Three-dimensional tissue engineering of hyaline cartilage: comparison of adult nasal and articular chondrocytes. Tissue Eng 8: 817-826.

Kanczler JM, Oreffo RO (2008) Osteogenesis and angiogenesis: the potential for engineering bone. Eur Cell Mater 15: 100-114.

Karlsson C, Brantsing C, Svensson T, Brisby H, Asp J, Tallheden T, Lindahl A (2007) Differentiation of human mesenchymal stem cells and articular chondrocytes: analysis of chondrogenic potential and expression pattern of differentiation-related transcription factors. J Orthop Res 25: 152-163.

Kern S, Eichler H, Stoeve J, Kluter H, Bieback K (2006) Comparative analysis of mesenchymal stem cells from bone marrow, umbilical cord blood, or adipose tissue. Stem Cells 24: 1294-1301.

Kusuhara H, Isogai N, Enjo M, Otani H, Ikada Y, Jacquet R, Lowder E, Landis WJ (2009) Tissue engineering a model for the human ear: assessment of size, shape, morphology, and gene expression following seeding of different chondrocytes. Wound Repair Regen 17: 136-146.

Lee RH, Kim B, Choi I, Kim H, Choi HS, Suh K, Bae YC, Jung JS (2004) Characterization and expression analysis of mesenchymal stem cells from human bone marrow and adipose tissue. Cell Physiol Biochem 14: 311-324.

Lee CS, Moyer HR, Gittens RA, Williams JK, Boskey AL, Boyan BD, Schwartz Z (2010) Regulating in vivo calcification of alginate microbeads. Biomaterials 31: 4926-4934.

Liu TM, Martina M, Hutmacher DW, Hui JH, Lee EH, Lim B (2007) Identification of common pathways mediating differentiation of bone marrow- and adipose tissue-derived human mesenchymal stem cells into three mesenchymal lineages. Stem Cells 25: 750-760.

Lohan A, Marzahn U, El Sayed K, Haisch A, Kohl B, Muller RD, Ertel W, Schulze-Tanzil G, John T (2011) In vitro and in vivo neo-cartilage formation by heterotopic chondrocytes seeded on PGA scaffolds. Histochem Cell Biol 136: 57-69.

Malicev E, Kregar-Velikonja N, Barlic A, Alibegovic A, Drobnic M (2009) Comparison of articular and auricular cartilage as a cell source for the autologous chondrocyte implantation. J Orthop Res 27: 943-948.

Mehlhorn AT, Niemeyer P, Kaiser S, Finkenzeller G, Stark GB, Sudkamp NP, Schmal H (2006) Differential expression pattern of extracellular matrix molecules during chondrogenesis of mesenchymal stem cells from bone marrow and adipose tissue. Tissue Eng 12: 2853-2862.

Mow VC, Guo XE (2002) Mechano-electrochemical properties of articular cartilage: their inhomogeneities and anisotropies. Annu Rev Biomed Eng 4: 175-209.

Muir H (1995) The chondrocyte, architect of cartilage. Biomechanics, structure, function and molecular biology of cartilage matrix macromolecules. Bioessays 17: 10391048.

Naumann A, Dennis JE, Aigner J, Coticchia J, Arnold J, Berghaus A, Kastenbauer ER, Caplan AI (2004) Tissue engineering of autologous cartilage grafts in three- 
dimensional in vitro macroaggregate culture system. Tissue Eng 10: 1695-1706.

Noel D, Caton D, Roche S, Bony C, Lehmann S, Casteilla L, Jorgensen C, Cousin B (2008) Cell specific differences between human adipose-derived and mesenchymal-stromal cells despite similar differentiation potentials. Exp Cell Res 314: 1575-1584.

Panossian A, Ashiku S, Kirchhoff CH, Randolph MA, Yaremchuk MJ (2001) Effects of cell concentration and growth period on articular and ear chondrocyte transplants for tissue engineering. Plast Reconstr Surg 108: 392-402.

Pfaffl MW, Tichopad A, Prgomet C, Neuvians TP (2004) Determination of stable housekeeping genes, differentially regulated target genes and sample integrity: BestKeeperExcel-based tool using pair-wise correlations. Biotechnol Lett 26: 509-515.

Pittenger MF, Mackay AM, Beck SC, Jaiswal RK, Douglas R, Mosca JD, Moorman MA, Simonetti DW, Craig S, Marshak DR (1999) Multilineage potential of adult human mesenchymal stem cells. Science 284: 143-147.

Puelacher WC, Kim SW, Vacanti JP, Schloo B, Mooney D, Vacanti CA (1994) Tissue-engineered growth of cartilage: the effect of varying the concentration of chondrocytes seeded onto synthetic polymer matrices. Int J Oral Maxillofac Surg 23: 49-53.

Rebelatto CK, Aguiar AM, Moretao MP, Senegaglia AC, Hansen P, Barchiki F, Oliveira J, Martins J, Kuligovski C, Mansur F, Christofis A, Amaral VF, Brofman PS, Goldenberg S, Nakao LS, Correa A (2008) Dissimilar differentiation of mesenchymal stem cells from bone marrow, umbilical cord blood, and adipose tissue. Exp Biol Med 233: 901-913.

Rider DA, Dombrowski C, Sawyer AA, Ng GH, Leong D, Hutmacher DW, Nurcombe V, Cool SM (2008) Autocrine fibroblast growth factor 2 increases the multipotentiality of human adipose-derived mesenchymal stem cells. Stem Cells 26: 1598-1608.

Sakaguchi Y, Sekiya I, Yagishita K, Muneta T (2005) Comparison of human stem cells derived from various mesenchymal tissues: superiority of synovium as a cell source. Arthritis Rheum 52: 2521-2529.

Seda Tigli R, Ghosh S, Laha MM, Shevde NK, Daheron L, Gimble J, Gumusderelioglu M, Kaplan DL (2009) Comparative chondrogenesis of human cell sources in $3 \mathrm{D}$ scaffolds. J Tissue Eng Regen Med 3: 348-360.

Segawa Y, Muneta T, Makino H, Nimura A, Mochizuki T, Ju YJ, Ezura Y, Umezawa A, Sekiya I (2009) Mesenchymal stem cells derived from synovium, meniscus, anterior cruciate ligament, and articular chondrocytes share similar gene expression profiles. J Orthop Res 27: 435-441.

Stoddart MJ, Grad S, Eglin D, Alini M (2009) Cells and biomaterials in cartilage tissue engineering. Regen Med 4: 81-98.

Tay AG, Farhadi J, Suetterlin R, Pierer G, Heberer M, Martin I (2004) Cell yield, proliferation, and postexpansion differentiation capacity of human ear, nasal, and rib chondrocytes. Tissue Eng 10: 762-770.

Tomiya M, Fujikawa K, Ichimura S, Kikuchi T, Yoshihara Y, Nemoto K (2009) Skeletal unloading induces a full-thickness patellar cartilage defect with increase of urinary collagen II CTx degradation marker in growing rats. Bone 44: 295-305.

van Osch GJVM, Mandl EW, Jahr H, Koevoet W, NolstTrenite G, Verhaar JA (2004) Considerations on the use of ear chondrocytes as donor chondrocytes for cartilage tissue engineering. Biorheology 41: 411-421.

Vinardell T, Sheehy EJ, Buckley CT, Kelly DJ (2012) A comparison of the functionality and in vivo phenotypic stability of cartilaginous tissues engineered from different stem cell sources. Tissue Eng Part A 18: 1161-1170.

Winter A, Breit S, Parsch D, Benz K, Steck E, Hauner H, Weber RM, Ewerbeck V, Richter W (2003) Cartilagelike gene expression in differentiated human stem cell spheroids: a comparison of bone marrow-derived and adipose tissue-derived stromal cells. Arthritis Rheum 48: 418-429.

Wong M, Siegrist M, Wang X, Hunziker E (2001) Development of mechanically stable alginate/chondrocyte constructs: effects of guluronic acid content and matrix synthesis. J Orthop Res 19: 493-499.

Xu JW, Zaporojan V, Peretti GM, Roses RE, Morse KB, Roy AK, Mesa JM, Randolph MA, Bonassar LJ, Yaremchuk MJ (2004) Injectable tissue-engineered cartilage with different chondrocyte sources. Plast Reconstr Surg 113: 1361-1371.

Yaeger PC, Masi TL, de Ortiz JL, Binette F, Tubo R, McPherson JM (1997) Synergistic action of transforming growth factor-beta and insulin-like growth factor-I induces expression of type II collagen and aggrecan genes in adult human articular chondrocytes. Exp Cell Res 237: 318-325.

Yoshimura H, Muneta T, Nimura A, Yokoyama A, Koga H, Sekiya I (2007) Comparison of rat mesenchymal stem cells derived from bone marrow, synovium, periosteum, adipose tissue, and muscle. Cell Tissue Res 327: 449-462.

Zhang L, Spector M (2009) Comparison of three types of chondrocytes in collagen scaffolds for cartilage tissue engineering. Biomed Mater 4: 045012.

Zuk PA, Zhu M, Ashjian P, De Ugarte DA, Huang JI, Mizuno H, Alfonso ZC, Fraser JK, Benhaim P, Hedrick MH (2002) Human adipose tissue is a source of multipotent stem cells. Mol Biol Cell 13: 4279-4295.

Zuk PA, Zhu M, Mizuno H, Huang J, Futrell JW, Katz AJ, Benhaim P, Lorenz HP, Hedrick MH (2001) Multilineage cells from human adipose tissue: implications for cell-based therapies. Tissue Eng 7: 211-228.

\section{Discussion with Reviewers}

Reviewer I: The authors imply that alginate might be a good carrier because encapsulated MSCs show diminished hypertrophy. However, could the mechanical properties of a cell/alginate hybrid ever be strong enough and if the alginate were gone, would the stabilising effect be lost?

Authors: We would like to emphasise that alginate did not seem to inhibit hypertrophic differentiation of bMSCs in vitro (alginate constructs containing bMSCs highly expressed hypertrophic markers such as COL10 and ALP after 2 and 5 weeks of in vitro culture). In our opinion, alginate prevented vascular ingrowth, which resulted in 
the absence of bone formation 8 weeks after subcutaneous implantation.

We agree with the reviewer that the biomechanical properties of the alginate used were low and inferior to that of native cartilages (e.g. ear cartilage: $\mathrm{E}_{\mathrm{eq}}$ $3.3 \pm 1.3 \mathrm{MPa}$ (Nimeskern et al., 2013); articular cartilage: $\mathrm{E}_{\mathrm{eq}} 10.9 \pm 5.0 \mathrm{MPa}$ (Richard et al., 2013)). However, alginate was chosen since it is being used as a cell carrier for clinical applications in cell-based cartilage repair (Almqvist et al., 2009; Selmi et al., 2008). Injected into a mechanically stable scaffold, alginate enables a homogeneous cell distribution into a mechanically stable environment. Moreover, it prevents cells from floating out while permitting nutrient diffusion and oxygen transfer to the encapsulated cells and thereby promotes the synthesis of cartilage-specific matrix components, such as GAGs and collagen type II (Hauselmann et al., 1992). Therefore, in our opinion, alginate injected into a mechanically stable scaffold could be an excellent therapy for cell-based cartilage repair. By the time alginate is completely gone (which will depend on the type of alginate and can take months), we hope the cartilage formed is mature and stable and will not undergo endochondral ossification anymore. However, this remains to be evaluated with long term in vivo experiments.

Reviewer I: What does it mean when large areas are negative for vimentin in Fig. 3E? Are some of the cells of host origin or is vimentin expression very variable?

Authors: Vimentins are class-III intermediate filaments and primarily expressed in cells of mesenchymal origin. Vimentins are attached to the nucleus, endoplasmic reticulum, and mitochondria. Strong positivity for the vimentin antibody is therefore demonstrated by a brown staining of the cell nucleus and cytoplasm. In our positive control of human cartilage, all cells were positive. The large area negative for vimentin is in our opinion the extracellular matrix, but we agree with the reviewer that some background stain was visible.

Reviewer I: The influence of alginate on construct 'ossification' should be questioned.

Authors: We have demonstrated that cell-free alginate constructs did mineralise in vivo, which was an unexpected finding and obviously not related to hypertrophic differentiation. It seemed that less metabolically active (meaning the colour of the culture medium was neutral to alkaline) alginate constructs were likely to mineralise in vivo. This is obviously a typical characteristic of alginate itself and it very valuable to know since alginate is actually being used in (experimental) clinical applications. Furthermore, cell-alginate constructs expressing hypertrophic genes in vitro, never calcified nor formed bone in vivo. This is a very promising outcome and indicates a possible benefit for the use of alginate as a cell-carrier for cartilage reconstruction.

Reviewer II: Unlike previous studies from the authors using MSCs seeded onto collagen scaffolds or in pellets, MSC-alginate constructs did not undergo endochondral ossification in vivo. Can the authors speculate as to why they believe this to be the case?

Authors: In our opinion, endochondral ossification requires 1) proper chondrogenic differentiation, 2) hypertrophic differentiation, and 3) a matrix that allows vessel ingrowth. We demonstrated that after chondrogenic induction (with TGF $\beta 1$ ), alginate constructs containing bone marrow-derived MSCs (bMSCs) chondrogenically differentiated and expressed hypertrophic markers in vitro, but did not form bone after subcutaneous implantation. Therefore, we believe that alginate did not necessarily inhibit hypertrophic differentiation of bMSCs, but prevented vessel ingrowth and subsequent bone formation.

Vessel ingrowth is extremely important for endochondral ossification. Angiogenesis in alginate is unlikely since vessels are unable to invade it. Although, alginate and other hydrogels have been used for research on bone regeneration (Park, 2011), modification of hydrogels with bioactive molecules (e.g. RGDs) seemed important allowing cell attachment and thereby vessel ingrowth.

To conclude, we believe that alginate differs from pellets or collagen scaffolds by preventing vascular ingrowth, thus resulting in the absence of bone formation 8 weeks after subcutaneous implantation.

Reviewer II: Why do the authors believe that they saw no difference in tissue mechanical properties in vitro despite differences in ECM accumulation between the different groups?

Authors: Extracellular matrix formation, and in particular collagen network formation, is a slow process in vitro. We have shown before that the mechanical properties of the matrix are not only determined by the amount of matrix components deposited, but also influenced by the cross-links between matrix molecules (i.e. collagen cross-links) (Bastiaansen-Jenniskens et al., 2008b). Moreover, the addition of TGF $\beta$ to chondrocytes has previously been demonstrated to result in less collagen cross-links in alginate, although it induced collagen cross-links in monolayer (Bastiaansen-Jenniskens et al., 2008a; Jenniskens et al., 2006). The optimal use of TGF $\beta$, and maybe the removal of it for a certain period before implantation, will be an interesting topic to consider in future research.

Reviewer III: The major issue I have with this study is how meaningful it is to culture and 're-differentiate' articular chondrocytes as if they were a chondro-progenitor population. They've already negotiated the chondrogenesis process.

Authors: We had two reasons for the set-up of our current study. 1) It has been previously shown that cultureexpanded chondrocytes that have not been re-differentiated in vitro can indeed form cartilage when implanted in vivo. Nevertheless, the cartilage formed is not always of good quality and will highly depend on the scaffold as well as on the cell density used (Marijnissen et al., 2000). In vitro re-differentiation, though not necessarily for 5 weeks, improves this. 2) Obviously, in order to form cartilage in ectopic locations, MSCs need chondrogenic induction 
in vitro. To be able to compare both chondrocytes and MSCs, we decided to expose all cell sources to an identical chondrogenic culture medium in vitro, that contained TGF $\beta 1$. Our experiments nicely confirmed that cartilage formation was hugely decreased for all cell sources in a subcutaneous environment when cultured without TGF $\beta 1$.

Reviewer III: The other interesting aspects of the study are the disparities between the matrix protein data and the modulus values, and between the hypertrophic marker expression and construct mineralisation. Unfortunately these disparities undermine the overall value of the manuscript.

Authors: There is a good possibility that the biochemical data are not directly correlated to the biomechanical data in these developing cartilage constructs, since the quality of the matrix is not only determined by the amount of matrix components deposited, but also influenced by the number of cross-links between matrix molecules (i.e. collagen cross-links) (Bastiaansen-Jenniskens et $a l .$, 2008b). Furthermore, we have performed a multiple regression analysis for all cell sources separately using only GAG and collagen deposition as independent variables. Presumably, other components such as the elastic fibre network in constructs containing ECs have influence on the biomechanical properties in vivo as well, although the exact contribution of these components to mechanical functionality is not fully understood in the literature.

We believe the lack of correlation between the hypertrophic differentiation and scaffold calcification is very interesting and important to realise. It teaches us some valuable things for future applications. Firstly, we have demonstrated that cell-free alginate constructs did mineralise in vivo, which was an unexpected finding and obviously not related to hypertrophic differentiation. It seemed that less metabolically active (meaning the colour of the culture medium was neutral to alkaline) alginate constructs were likely to mineralise in vivo. This is obviously a typical characteristic of alginate and it is very valuable to know because alginate is actually being using in (experimental) clinical applications. Furthermore, cell-alginate constructs expressing hypertrophic genes in vitro, never calcified nor formed bone in vivo. This is a very promising outcome and indicates a possible benefit for the use of alginate as a cell carrier for cartilage reconstruction.

Reviewer III: On a practical level, considering the doubling times, retention of chondrogenic potential, and the amount of donor tissue available, which source of chondrogenic cells do you think is the superior choice for clinical applications?

Authors: At the end of our manuscript we conclude that articular chondrocytes possess the highest chondrogenic capacity in vitro, while ear and nasal chondrocytes are most potent for cartilage regeneration after subcutaneous implantation, making them attractive cell sources for future cell-based cartilage repair.

\section{Additional References}

Almqvist KF, Dhollander AAM, Verdonk PCM, Forsyth R, Verdonk R, Verbruggen G (2009) Treatment of cartilage defects in the knee using alginate beads containing human mature allogenic chondrocytes. Am J Sport Med 37: 1920-1929.

Bastiaansen-Jenniskens YM, Koevoet W, de Bart AC, van der Linden JC, Zuurmond AM, Weinans H, Verhaar JA, van Osch GJ, Degroot J (2008b) Contribution of collagen network features to functional properties of engineered cartilage. Osteoarthritis Cartilage 16: 359-366.

Jenniskens YM, Koevoet W, de Bart AC, Weinans H, Jahr H, Verhaar JA, DeGroot J, van Osch GJ (2006) Biochemical and functional modulation of the cartilage collagen network by IGF1, TGFbeta2 and FGF2. Osteoarthritis Cartilage 14: 1136-1146.

Marijnissen WJ, van Osch GJ, Aigner J, VerwoerdVerhoef HL, Verhaar JA (2000) Tissue-engineered cartilage using serially passaged articular chondrocytes. Chondrocytes in alginate, combined in vivo with a synthetic (E210) or biologic biodegradable carrier (DBM). Biomaterials 21: 571-580.

Nimeskern L, Martinez Avila H, Sundberg J, Gatenholm P, Muller R, Stok KS (2013) Mechanical evaluation of bacterial nanocellulose as an implant material for ear cartilage replacement. J Mech Behav Biomed Mater 22: 12-21.

Park JB (2011) The use of hydrogels in bone-tissue engineering. Med Oral Patol Oral 16: E115-E118.

Richard F, Villars M, Thibaud S (2013) Viscoelastic modeling and quantitative experimental characterization of normal and osteoarthritic human articular cartilage using indentation. J Mech Behav Biomed Mater 24: 41-52.

Selmi TA, Verdonk P, Chambat P, Dubrana F, Potel JF, Barnouin L, Neyret P (2008) Autologous chondrocyte implantation in a novel alginate-agarose hydrogel: outcome at two years. J Bone Joint Surg Br 90: 597-604. 